\title{
CUIDADO INFANTIL E DESNUTRIÇÃO DE PRÉ-ESCOLARES: REGIŌES NORDESTE E SUL DO BRASIL
}

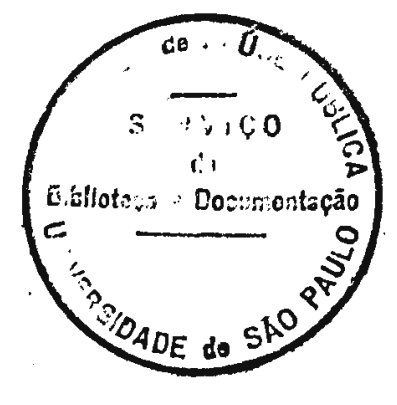

Maria Aparecida Alves Cardoso

vese

Tese apresentada à Faculdade de Saúde Pública da Universidade de São Paulo para a obtenção do título de Doutor em Saúde Püblica.

Orientadora: Maria Helena D'Aquino Benício

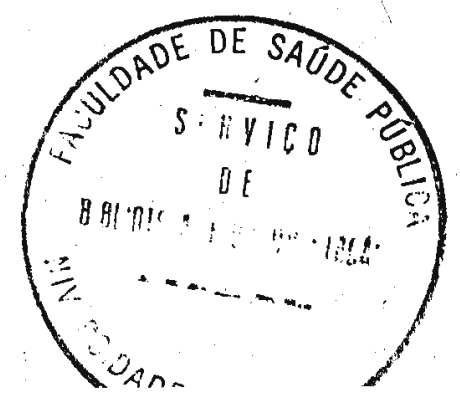


Este trabalho é dedicado à

Flavinha 
AGRADECIMENTOS

A Universidade Federal da Paraiba, Departamento de Tecnologia Quimica e de Alimentos, pela concessão de afastamento para a realização do curso de doutorado e à CAPES - Coordenação de aperfeiçoamento de pessoal de nivel superior - pela concessão de bolsa de estudo.

A Dra. Maria Helena D’Aquino Benício pela competente orientação em todas as fases da realização desta pesquisa.

Ao Dr. Carlos Augusto Monteiro pelo estímulo dado à realização deste estudo.

A Professora Maria do Rosário Dias de Oliveira Latorre pela valiosa contribuição na análise estatística.

Aos amigos que fiz na Faculdade de Saúde Pública pelo companheirismo durante a jornada de trabalho nesta dificil cidade de São Paulo. Agradecimento especial à Ana Claudia Peixoto de Vasconcelos, Sônia Venâncio e Ana Lúcia Brito pela inestimável ajuda na obtenção de bibliografia, em especial no período em que este trabalho foi realizado com régua e compasso da Paraiba.

A meus pais pelo. esforço em me dar a educação que não puderam ter. 
RESUMO

o cuidado infantil colocado no centro da análise da causalidaade da desnutrição destaca, neste estudo, a importância do papel desempenhado pela mulher na prevenção da doença. Realizado a partir de dados da Pesquisa Nacional de Saúde e Nutrição de 1989, este estudo abrangeu 3.529 crianças de 0 a 59 meses e analisou caracteristicas maternas e domiciliares definidoras do cuidado infantil em duas Regiões brasileiras, Região Nordeste e Região Sul, desdobradas nos seus contextos urbanos e rurais. Utilizou-se análise de regressão logística para avaliar os riscos associados aos diversos fatores em estudo. Destaca-se entre os resultados, que a exposição de crianças menores de 5 anos ao analfabetismo ou à baixa escolaridade materna constitui risco expressivo para a desnutrição em todas as regiốes estudadas. Outros fatores mostraram-se estatisticamente associados à desnutricão infantil, entre eles encontram-se a ausência de televisão no domicílio e o número de filhos em diferentes faixas etárias. 0 trabalho materno mostrou ser ora fator de risco, ora fator de proteção entre os diferentes contextos analisados. 0 estudo sugere a importância de se estender o acesso à educação e o tempo de escolarização da mulher. Concomitantemente, políticas relativas à natureza e remuneração do seu trabalho, expansão dos serviços de creche, acompanhadas de uma divisão de trabalho doméstico mais igualitária, devem abrir o caminho para cidadania da mulher com beneficios diretos para a saúde e nutriçá de seus filhos. 


\section{ABSTRACT}

The discussion of infant care as a basic determinant of child malnutrition brings to the fore the centrality of women roles to the process. A sample of 3.529 under 5 years old children corresponding to the population of Northeast and South regions were analysed focusing on maternal and household variables. The data came from the Pesquisa Nacional de Saúde e Nutrição carried out in Brazil in 1989

The analisys based on logistic regression models showed that under 5 children of illiterate or low educated mothers are exposed to an expressive risk for malnutrition both in urban and mural settings of the two regions. Some other factors were found to be statistically significant such as the non possession of TV set and the number of children of diferent ages. Maternal employment was a protective factor or a risk factor depending on the region. Besides the importance of extending women's education standards, it is suggested that public policies directed towards the improvement of women's work nature and salaries, the expansion of nursery services, as well as a more igualitarian division of domestic labor may pave the way for a women's dignity with straight benefits for children health and nutrition. 
INDICE

página

1. Introdução.......................... 10

1.1 Considerações iniciais................... 10

1.20 debate sobre a causalidade da desnutrição...... 13

1.3 Rumo aos novos caminhos................. 17

2. Cuidado infantil....................... 21

2.1 Conceituação.............................. 21

2.20 trabalho materno..................... 26

2.30 papel da escolaridade materna............ 30

2.4 Marco conceitual........................ 36

3. 0 "locus" do estudo e o status da mulher ......... 43

3.1. Diferenças regionais.................. 43

3.2. A mulher brasileira nas décadas de 70 e $80 \ldots \ldots 47$

3.2.1. O trabalho e a escolaridade.............. 49

3.3. Considerações finais................. 52

4. Hipóteses e Objetivos...................... 54

4.1 Hipóteses.............................. 54

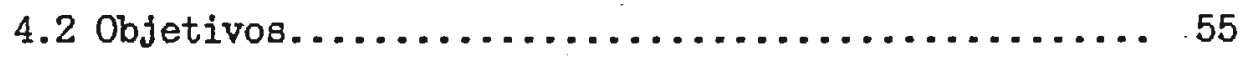

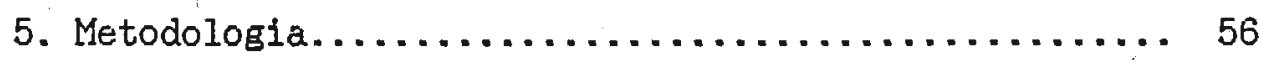

5.1. Fonte de dados $\ldots \ldots \ldots \ldots \ldots \ldots \ldots \ldots \ldots \ldots \ldots$

5.2. Amostra......................... 57

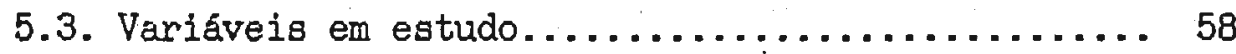

5.3.1. Variável dependente.............. 58

5.3.2. Caracteristicas matemas........... 58

5.3.3. Caracteristicas do domicilio........... 59 
5.4. Análise dos dados..................... 61

5.4.1. Distribuição e características dàs variáveis.. 61

5.4.2. Análise de regressão logística............ 62

5.4.2.1. Etapas da modelagem................ 63

6. Resultádos......................... 65

6.1. Análise univariada..................... 65

6.2 Análise de regressão logística............ 76

7. Discussão.......................... 81

7.1 Discussão dos resultados................ 81

7.2 Considerações finais................... 93

8. Conclusões............................. 102

9. Referências bibliográficas.................... 104

10. Anexo............................. 114 
Lista de tabelas, figuras e quadros

página

Figura 1 - Modelo causal simplificado do estado nutricional infantil........................... 41

Figura 2 - Modelo de determinação do cuidado infantil.......42

Tabela 1 - Mortalidade infantil. Nordeste e Sul. 1970 - 1988.. 46

Tabela 2 - Taxas de analfabetismo. Nórd. e Sul. 1970 - 1990... 46

Tabela 3 - Taxas de atividade feminina. Nordeste e sul.

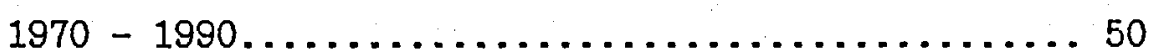

Tabela 4 - Mulheres analfabetas de 25 a 29 anos. Nordeste e Sul.

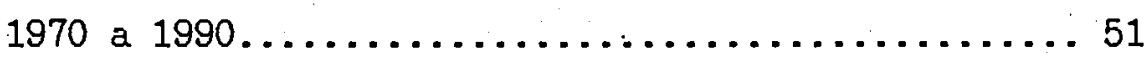

Tabela 5 - Mulheres com 4 ou mais anos de estudo......... 51

Tabela 6 - Distribuição da amostra segundo variầveis em estudo e associação com 0 déficit $A / I$. Nordeste urbano... 68

Tabela 7 - Distribuição da amostra segundo as variáveis em estudo e associação com o déficit $A / I$. Nordeste mural.... 70 Tabela 8 - Distribuição da amostra segundo as variâveis em estudo e associação com o déficit $A / I$. Sul urbano....... 72

Tabela 9 - Distribuição da amostra segundo as variáveis em estudo e associação com o déficit $A / I$. Sul rural....... 74

Quadro 1 - Variáveís selecionadas para a análise de regressão logistica...........................67

Quadro 2 - Modelo de regressão logistica. Nordeste urbano.....78

Quadro 3 - Modelo de regressáo logistica. Nordeste rural. . ... 79

Quadro 4 - Modelo de regressão logística. Sul urbano........79 
Quadro 5 - Modelo de regressão logística. Sul rural ........ 80

Quadro 6 - Etapas da modelagem. Nordeste Urbano............115

Quadro 7 - Etapas da modelagem. Nordeste mural............117

Quadro 8 - Etapas da modelagem. Sul Urbano.................119

Quadro 9 - Etapas da modelagem. Sul mural.................121

Tabela $10^{\circ}$ - № de casos com inform. completas no modelo final

de regressão logística. Nordeste urbano..........122

Tabela 11 - № de casos com inform. completas no modelo final de regressão logística. Nordeste rural .........123

Tabela 12 - № de casos com inform. completas no modelo final de regressão logística. Sul urbano............ 124

Tabela 13 - № de casos com inform. completas no modelo final

de regressão logística. Sul rural ........... 124 


\section{INTRODUÇณ̃O}

\subsection{Considerações iniciais}

Conforme indicam dois inquéritos antropométricos realizados em nível nacional, a prevalência da desnutrição infantil no Brasil cai em mais de $60 \%$ da década de 70 para a década de 80 .

A PNSN (Pesquisa Nacional de Saúde e Nutrição) realizada em 1989 constatou que $15,4 \%$ da população de menores de cinco anos apresentava desnutrição crônica (Monteiro e col.1992c) ^. A PNSN revelou ainda a existência de taxas de desnutrição bastante discrepantes entre as diferentes regiões brasileiras. 0 ENDEF (Estudo Nacional da Despesa Familiar), 15 anos antes, indicava um nivel de desnutrição sensivelmente mais alto para o pais como um todo. A comparação entre as duas pesquisas mostra ainda que a redução da prevalência de desnutrição não ocorreu de forma homogênea ao longo do país, tendo sido mais acentuada nas regiões mais desenvolvidas como o Sul e o Sudeste brasileiros, agravando desta maneira, as desigualdades anteriormente existentes entre as macro-reglóes (Monteiro e col. 1992a).

Estes dados suscitam, de início, inúmeras indagações, já que a queda observada nas taxas de desnutrição infantil mostra-se incoerente com a situação econômica do país no período em questão. No inicio dos anos 70, a economia brasileira experimentava taxas de crescimento jamais vistos em sua história, 
correspondendo ao que se convencionou denominar de "milagre brasileiro".

No periodo do "milagre", atraves da intensificação de um processo iniciado em décadas anteriores, o país consolida sua industrialização, moderniza seu aparato produtivo, tornando-se industrializado e urbano. No entanto, com a desaceleração do crescimento econômico instalada com o fim do "milagre " em 1973, - país assiste ao desencadear de um processo que val se acentuando até chegar a provocar, no final da década de 70 , elevadas taxas de inflação, desemprego e conseqüente deterioração da qualidade de vida dos trabalhadores. Ao contrário do que acontece nos paises desenvolvidos, onde o poder aquisitivo é maior e os trabalhadores contam com mecanismos de proteção do estado, a recessão econômica no Brasil compromete de forma direta as condições de vida de grande proporção da população, que depende dos rendimentos de mão-de-obra não qualificada e dos investimentos públicos na área social (Serra,1982). Na década de 80, conhecida como a década perdida, este quadro não apresenta melhoras. Com exceçăo de un breve periodo de melhoria econômica devido a incentivos dirigidos às exportações, que ocorre por volta de 1983, o período continua marcado por recessão e planos antinflacionérios mal sucedidos.

Se a desnutriçáa $\epsilon$ un fenômeno inquestionavelmente ligado a pobreza, como explicar a significante melhoria da situação nutricional da criança brasileira num periodo de tantas 
adversidades econômicas? Estudos recentes buscam explicar o fenômeno ocorrido no Brasil nas últimas décadas através de análises que incluem outros fatores além das variáveis diretamente relacionadas à renda. Monteiro e col.(1992a) analisando a melhoria das condições de nutrição infantil nas décadas de 70 e 80 , frente ao comportamento de outros indicadores sociais e econômicos, atribuem papel determinante à grande expansão de serviços e programas governamentais, ambos favorecidos pela conjuntura demográfica do período.

Partindo de uma análise baseada no nível de pobreza das pessoas e familias brasileiras, Iunes \& Monteiro (1993) identificam dois períodos distintos na economia brasileira onde no primeiro, que corresponde à década de 70 , a melhoria observada no estado nutricional infantil não seria incompativel com a situação econômica das famílias, já que "os beneficios do rápido crescimento econômico do inicio dos anos 70 não foram inteiramente perdidos pelos pobres, havendo sienificantes reduç̃es durante esta decada na proporçăo dos individuos abaixo da linha de pobreza, particularmente até $1976^{\prime \prime}=$. Por outro lado, mostram os autores, na década de 80 , continua-se a se observar uma tendência de redução da desnutrição infantil enquanto que os indicadores de renda indicam aumentos na proporcão de pessoas abaixo da linha de pobreza e deterioração na distribuição de renda. Assim, a explicação da continuada melhora deve estar em outros fatores que não as variáveis diretamente relacionadas com a renda. E os autores concluem que "ao longo da 
década de 80 todo e qualquer progresso no estado nutricional infantil teria que ser essencialmente atribuido à ampliação do acesso da população a serviços públicos". Na verdade, observa-se que o comportamento de indicadores relacionados a gastos e cobertura de serviços públicos (saneamento, saúde e educação) nos anos 80 é coerente com a hipótese dos autores.

A incoerência entre dados econômicos e indicadores da saũde infantil também tem sido constatada em outras partes do mundo. Alèm do Brasil (Gross et al.1987, Monteiro et al,1992b), o Chile, Costa Rica, Jamaica, Kerala(India), Sri Lanka (Dreze \& Sen,1989); Botswana e Zimbabwe (Cornia G. et al. 1987); têm sido relatados como exemplos de casos onde a nutrição apresentou melhoras superiores àquelas que poderiam ser esperadas pela situação econômica, ou ainda casos onde o estado nutricional teria sido protegido pela recessão econômica.

1.2. 0 debate sobre a causalidade da desmutrição

Estudos da natureza destes, citados acima, colocam em questionamento as posições fimmadas no grande fómum sobre alimentação e nutrição de 1974: a Conferência Mundial da Alimentação. As conclusões do encontro estabeleciam que a solução para os problemas da desnutrição passavam necessariamente por questơes de politica econômica, já que a sua origem estava diretamente relacionada à pobreza. Este fato faz mudar o discurso 
e a postura das principais organizaçes internacionais do setor como a FAO, OMS e UNICEF. Para melhor conferirmos alguns passos e desencontros deste caminho, é importante que facamos, mesmo que de forma multo breve, algumas considerações acerca da evolução do debate sobre a causalidade da desnutrição.

Nas décadas de 1940 e 1950 a desnutrição era ora concebida como problema médico (de carências/mal absorção de vitaminas e proteínas), ora como problema técnico associado a questões como o crescimento populacional e a produção de alimentos. Assim, o problema nutricional do Terceiro Mundo estaria assentado na falta de proteínas e micronutrientes ao lado de problemas agrícolas e populacionais. Era preciso resolver o "protein gap" e como solução verifica-se, na ocasião, uma grande transferência de alimentos proteicos (em geral subprodutos industriais como 0 leite em pó) no sentido norte-sul do globo, ao mesmo tempo em que se estimula a pesquisa de alimentos mais ricos em proteína nos países pobres( como por ex. a produção da Incaparina, e da "single cell protein").

A reavallação das necessidades protelcas ocorridas no infcio dos anos 70 permite uma melhor compreensão das interações existentes entre o complexo energia-proteina, e faz mudar os rumos do debate. As conclusões da Conferência Mundial da Alimentação, de 1974, colocam o deficlt calórico como questăo central da problematica nutricional, quebrando-se o "mito da proteína". A pobreza é então estabelecida como a causa maior da 
desnutriçăo e passa-se a se enfatizar que a distribuicăo de alimentos ou o acesso aos alimentos pelos pobres era crucial. No Brasil instala-se o PRONAN (INAN - 1976), um programa que visava atuar sobre o problema nutricional inserindo-o dentro do contexto mais geral do desenvolvimento. 0 seu discurso teórico, bastante avançado para a época, abordava basicamente a necessidade da distribuição da renda e da racionalização da produção e distribuição dos alimentos.

Neste período, as implicações políticas da pobreza passam a predominar e ideologizar os discursos que vêem a denúncia como o instrumento mais eficaz no controle da desnutrição. Admitia-se que sem uma reforma agrárla e um diferente padrão de distribuição de renda como medidas de erradicação da pobreza nada se podia fazer para prevenir a desnutrição.

Esta nova postura foi responsável pelo surgimento, em diversos paises, de planos bastante ambiciosos que chegavam a colocar as questóes nutricionais em direta competição com todos os outros aspectos do desenvolvimento sócio-econômico. Tais planos, no entanto, no decorrer do seu encaminhamento, quer por questões operacionais, politicas, ou mesmo por sua própria superabrangência acabavam por não ser cumpridos (Gillespie \& Mason 1991).

Por outro lado, alguns governos confrontam o problema de forma mais direta passando a adotar medidas bastante concretas 
como a estabilização de preços de alimentos, políticas de segurldade social, serviços de saúde especiais para mulheres e crianças, e outras. Este tipo de atitude se dá dentro do clima de "boom" econômico que caracterizava o início dá década de 1970. A dispontbilidade de recursos da época leva, inclusive, aiguns países a investir em serviços mesmo sem a sua inserção dentro de políticas especificas claramente orientadas ao combate à fome e à miséria. Um exemplo típico desta situação pode ser encontrado no Brasil, onde vultosos investimentos foram dirigidos ao setor de serviços, principalmente nas áreas de saúde, educaçăo, e saneamento. Análises mais recentes mostram que estas politicas públicas, quer tenham sido ou não diretamente dirigidas ao combate da fome e à melhoria das condições de vida dos estratos mais pobres das populaçőes do Terceiro Mundo, produziram resultados positivos no campo da saúde e nutrição infant1l. São estes investimentos em serviços que vêm explicando a queda dos níveis de desnutrição em diferentes países e regiões.

Im suma, a evolução do pensamento sobre a rede de causalidade da desnutrição nesta segunda metade do século, passa de uma visão técnica e/ou médica para um abordagem mais ampla, atraves da inserção do problema dentro do contexto político e social das nações. O espaço para a análise da questão amplia-se agora com a concepsão de um processo ainda mais amplo onde se observa que, embora a reduçá da pobreza seja um ponto chave para a garantia da segurança alimentar do domicilio, a manutenção de um estado nutricional adequado transcende a questăo econômica e é 
influenciada por outros fatores, entre os quais pode-se destacar a disponibilidade de serviços de saúde, educação e saneamento.

\subsection{Rumo aos novos caminhos}

A última reunião do Comitê de Nutrição das Nações Unidas (UNITED NATIONS,1991), em face de evidências recentes e a partir de relatórios e documentos chave de organizacões internacionais sobre a questão da desnutrição no Terceiro Mundo (UNICEF 1990; FAO/WHO, 1990), propõe uma nova metodologia para se confrontar a desnutricão nos anos 90 . 0 documento agrupa as causas da desnutrição proteico calórica crônica em três grandes "grupos problema", os quais reproduzimos abaixo:

a) "Seguranca alimentar do domicilio": refere-se ao acesso aos alimentos necessários para garantir uma vida saudável e ativa a todos os membros do domicílio. Problemas neste setor podem estar associados a produção de alimentos e/ou poder aquisitivo da familia.

b) "O complexo infecção-desnutrição": o inter-relacionamentc sinérgico entre a desnutrição e as infeç̧ões consiste na principal causa de saúde precária e morte prevenivel, em especia] de crianças. 
c) "A mulher - sua capacidade de cuidar adequadamente da criança e seu controle sobre os recursos disponíveis": esta questão pode ser vista mais como um ponto crucial de ligação entre os dois primeiros gmupos acima do que como um Erupo problema. A questão do gênero representa uma dimensão abrangente de muitos dos problemas nutricionais. 0 acesso e controle de recursos pela mulher, governados pelo seu status econômico e social, condicionam seu potencial de prover alimentos para a familia bem como de cuidar adequadamente de suas criancas.

0 grande avanço nessa nova abordagem dos problemas nutricionais é a introduçăo da mulher como um dos pontos chave na discussão. Este fato é importante não apenas pela atualidade da questão do gênero e da sua interface com as ciências da saúde, mas essencialmente pelo crescente reconhecimento da importância do papel desempenhado pela mulher em todos os aspectos da nutrição e em especial da nutrição infantil (United Nations 1990; Holmboe-Ottesen e col., 1989).

o papel central desempenhado pela mulher em direção ao estado nutricional da criança se dá através do cuidado infantil. A sua capacidade de cuidado vai modular o desempenho dos outros "grupos problema", ou seja, da questão do acesso ao alimento e da prevenção contra infecções. Uma "proxy" para a avaliação da capacidade materna de cuidado infantil pode ser obtida pelo nivel de escolaridade das mulheres. A analise de dados estatisticos de diferentes regioes do globo sugere a existência de associação 
entre esta variável - entre outras características maternas - e as condições de saúde infantil (Banco Kundial,1990; UNDP, 1991). No Brasil observa-se a tendência clara de queda do analfabetismo e do aumento do número de anos de escolaridade na populaçăo feminina em idade reprodutiva nas décadas de 70 e 80 . Para se ter uma idéia da magnitude desta melhora, a taxa de alfabetização de mulheres na faiza etária de 20 a 29 anos sobe de $70,1 \%$ em 1970 (FIBGE,1972) para 84,7\% em 1978 (FIBGE,1979), alcançando 91,3\% em 1989 (INAN, 1990a).

A escolaridade da mulher permeia, como discutiremos no capitulo seguinte, toda a complexa rede de sua inserção na sociedade, desde a sua esfera doméstica, definindo comportamentos e padrớes de consumo, até a sua posiça frente a instituiçóes e mercado de trabalho. A forma como a mulher dedica seu tempo de atenção aos filhos, seja diretamente, ou delegando a terceiros este cuidado, certamente será influenciada pelo seu grau de instrução.

Além da escolaridade, outros fatores pertencentes ao cotidiano da mulher - como por exemplo a disponibilidade de tempo definida em função do seu status de trabalho ou mesmo do número de filhos, a disponibilidade de serviços e de informação - estão associados a sua capacidade de prover adequadamente o cuidado Infantil. 
No próximo capitulo estaremos abordando mais a fundo a questão do cuidado infantil através da revisão da literatura. Será discutido o papel da mulher e mãe em função de suas características, práticas e atitudes, social ou culturalmente determinadas, que podem afetar a sua contribuição à saúde e sobrevivência infantil. Desta forma, o final do capitulo 2 apresenta o marco conceitual deste trabalho.

0 capitulo 3 faz uma contextualização das regiões enfocadas estudo neste estudo, ou seja, das macro-regiões Nordeste e Sul, numa tentativa de verificar o "ambiente" sócio-econômico bem como a evolução do status da mulher durante as décadas de 70 e 80.0 capítulo 4 apresentará os objetivos e hipóteses deste trabalho. A metodologia empregada, bem como os resultados obtidos serão dispostos nos capítulos 5 e 6 respectivamente, e, a seguir, nos capitulos 7 e 8, serão colocadas a discussão e as conclusões deste estudo.

Notas

1. Este valor corresponde a proporção de crianças que apresentaram indice altura/idade inferiores a -2 scores $z$.

2. A linha de pobreza utilizada pelos autores foi de um quarto do salário mínimo per capita. 


\section{O CUIDADO INFANTIL}

\subsection{Conceituação}

o cuidado infantil é visto aqui como uma das três condições necessárias para a manutenção de um estado nutricional adequado, as outras duas correspondendo à seguridade alimentar do domicílio e ao controle de doenças infecciosas, conforme citado anteriormente na introdução deste trabalho. Parte-se do princípio de que a um dado nível mínimo de disponibilidade de recursos no domicilio, em especial de alimentos, de saneamento/higiene e de acesso a serviços, o estado nutricional de seus membros vai depender muito da forma como a situação é enfrentada, especialmente pela mulher. Muitos dos fatores subjacentes a esta forma de enfrentamento - como por exemplo a educação, habilidades e o tempo disponível da mulher - e suas ligações imediatas com a nutrição - como por exemplo a própria saúde materna, o aleitamento - podem e devem ser trabalhados através de politicas páblicas devendo produzir un resultado positivo na redução da desnutrição. Já outros fatores são determinados pela organização social, padrões de comportamento e divisão de trabalho entre os individuos do domicillio. A conjunção destes fatores determina a qualidade do cuidado infantil e será daqui em diante referida como a capacidade de cuidado infantil. 
0 "cuidado" fol definido pelo Comitê de Nutrição das Nações Unidas (Gillespie \& Mason 1991), da seguinte forma:

"De uma maneira geral, o "cuidar" refere-se ao estabelecimento, tanto a nivel de domicílio como de comunidade, de tempo, atenç̃o e condiçôes básicas para o suprimento das necessidades físicas, mentais e sociais da criança e outros membros da familia. 0 "cuidar" leva a una otinlzaçâo dos recursos humanos, econômicos e organizacionais. Num outro extremo, a falta do "cuidar" é a negligencia. Em particular no contexto da nutrição infantil, o "cuidar" procura a otimização do uso dos recursos alimentares do domicilio para a alimentação infantil, a otimizaçâo do uso dos recursos humanos através dos laços famlliares (ou outros) para a proteção contra infeções e cuidados com a criança doente ou outros membros vulneráveis' (exemplo: excepcionais ou idosos)".

No âmbito do domicilio, o cuidado infantil está associado, potencialmente, a todos os seus membros, sejam eles do sexo masculino ou feminino, no entanto, na prática, a principal responsabilidade pelo "cuidado" recai sobre a mulher. Dias(1986) mostra que, no caso do Brasil, a mulher da classe trabalhadora, dentro das limitaçסes impostas pela precariedade das condiçós de vida, se transforma freqüentemente numa verdadeira "sanitarista de pés descalços". Esta mesma mulher desempenha, muitas vezes, o papel de provedora de renda para a sobrevivêncla da família. Portanto sua habilidade para ajustar as suas diversas atividades e demandas dentro do seu tempo limitado é que vai 
definir o grau de possibilidade de manter um ambiente limpo e saudável, de garantir os necessários e adequados cuidados infantis e, de fornecer, preparar e servir alimentos para todos os membros da familia e, em particular, para as crianças.

Aqui surge um primeiro aspecto fundamental do quotidiano da mulher associado à questão da nutrição e saúde: o tempo. Usualmente esquecido pelos planejadores da área que tendem a concentrar a discussão sobre temas como a disponibilidade de alimentos e prevenção de doenças infecciosas, o tempo revela uma outra dimensăo do problema: a dimensão dos problemas nutricionais inserida dentro do contexto do gênero.

A análise do cuidado infantil dentro desta perspectiva exige que se destaque dois aspectos da questão. De um lado, se tem o ambiente doméstico cuja abordagem nos remete diretamente à questão da divisão de trabalho intra-domiciliar, com todos os seus possiveis desdobramentos e implicações sobre o cuidado da criança. Nesse sentido, $e$ de fundamental importância o valor atribuido ao cuidado pelos membros da família. Engle (1992) chama a atenção para uma importante conceituação na análise do cuidado infantil. A autora divide as condutas de cuidado entre aquelas que podem levar a criança a um nivel minimamente saudavel ("compensatory behaviours") e aquelas orientadas para a melhoria das potencialidades, crescimento e desenvolvimentoda criança ("Enhancement behaviours"). Assim, ura menor valorizaça do cuidado infantil por parte dos pais os levaria a utilizar ou 
desviar um tempo extra, um recurso fundamental para o cuidado, para a realização de outras atividades como o lazer ou trabalho, em detrimento do bem estar da criança.

Por outro lado, é necessário considerar o trabalho da mulher fora do domicílio (dentro da esfera produtiva) e suas implicações para o cuidado infantil. Como será discutido mais adiante, esta é uma questão bastante complexa uma vez que limita o tempo disponivel para o cuidado. Nesse sentido, é importante a organização das mulheres em busca de soluções para adequar suas condições de trabalho às necessidades de cuidado dos filhos. Esta luta, que inclui a reivindicação de creches próximas ao local de trabalho, a negociação com patrões acerca da flexibilizącão dos horários de trabalho torna-se cada vez mais importante para a mulher trabalhadora em geral. Vale salientar que determinadas características do trabalho feminino favoráveis ao cuidado infantil, em especial a flexibilização dos horários de trabalho, tem sido prerrogativas de mulheres mais escolarizadas e de maior capacitação profissional, enquanto que as crianças de mães menos favorecidas ficam privadas do seu direito ao cuidado (Van Esterick 1991).

A discussão sobre a disponibilidade de tempo para o cuidado da criança fe fundamental já que, uma boa adequação nutricional não depende apenas da disponibilidade de alimentos ou dos meios para adquiri-los. Para que os alimentos sejam consumidos eles precisam de ser antes comprados, preparados, servidos, e, no caso 
das crianças menores, administrados: No caso das crianças no primeiro ano de vida, ainda, há que se considerar o tempo necessário para o aleitamento materno.

0 aleitamento materno constitui-se num aspecto fundamental do cuidado infantil. A composição química bem como as propriedades biológicas do leite materno garantem à criança uma nutriçăo adequada e a proteção contra uma série de infecçőes viróticas e bacterianas (Jelliffe \& Jelliffe,1986). Pressupóe a proximidade e o apego necessários ao desenvolvimento da relação emocional mãe-filho. A amamentação propicia, assim, um contato físico de fundamental importância para o desenvolvimento psicológico, afetivo e cognitivo da criança contribuindo desta maneira para a expansão do seu potencial enquanto ser humano (Lucas e col.1991; Walter,1993; Engle,1992). Conforme observa Longhurst (1993 e 1995), o aleitamento materno constitui-se na única ação humana que reune em sí as capacidades de nutrir, prover saúde e aconchego, trazendo em seu bojo todos os aspectos positivos do contato frequente tão importante para a mãe e criança e que implica necessariamente numa melhor qualidade de cuidado.

Além dos possiveis prejuízos sobre a alimentação, a limitação do tempo da mãe pode afetar a criança de outras maneiras na medida em que pode levar a uma menor utilizaçáo dos serviços de saúde e a menores cuidados de higiene, tanto no 
domicilio como com as proprias criancas; estes revezes afetariam a proteção infantil contra as infecções.

Verifica-se, portanto, que o fator tempo exerce um papel fundamental sobre o cuidado infantil estando relacionado com a "seguridade alimentar do domicilio" e com o "complexo infeccấo desnutrição". Na verdade um adequado cuidado infant1l pode ser considerado uma função da alocação de tempo e renda. Kumar (1983) nominou a combinação entre renda e tempo, neste contexto, como a "renda real do domicilio"

\subsection{O trabalho da mulher}

Um dos pontos-chave na discussão sobre o tempo materno assoclado ao cuidado infantil é a questão do trabalho da mãe em atividades geradoras de renda. Na década de 80 , 0 debate sobre a divisão do tempo da mulher entre atividades produtivas (geradoras de renda) e reprodutivas (domésticas) girava em torno de dols pólos. De um lado, uma escola de pensamento colocava a mulher como um dos agentes centrais do desenvolvimento enfatizando a importáncia do seu desempenho no setor produtivo, năo se importando com suas responsabilidades sobre o cuidado infantil. Por outro lado os proponentes do "bem estar infantil" viam as mulheres como instmumentos de produçăo de crianças saudáveis, negligenciando assim a importancia do trabalho produtivo das mulheres, em especial, daquelas de baixa renda (Leslie \& 
Paolisso, 1989). Na verdade, esta é uma questão complexa, fato que pode ser avaliado pelos resultados conflitantes obtidos a partir de diferentes estudos conduzidos acerca da questão nos últimos anos, como veremos abaixo.

Tanto o senso comum como evidências empiricas sugerem que a renda da mulher é mais provável de ser dispendida em alimentos e outras necessidades básicas do domicilio do que a renda auferida pelos homens (Rogers \& Youssef,1988). Isto é explicado, no mínimo, pelo fato de que são as mulheres quem, em última instância, são as responsáveis pela alimentação e pelo bem estar infantil.

Num estudo conduzido na Guatemala, Engle (1993) verificou que quanto maior era a contribuição da mãe para a renda familiar melhor era o estado nutricional dos seus filhos. Assim, qualquer aumento na renda da mulher é mais provável de promover melhorias no estado nutricional infantil, do que aumentos na renda do domicilio como um todo. Este fato reforça a hipótese de que o aumento do poder econômico e, consequentemente, da autonomia da mulher viria a contribuir para o bem estar infantil.

No entanto, na medida em que a mãe destina mais tempo para atividades produtivas ela reduz o tempo dedicado a atividades domésticas, incluindo o preparo de alimentos e o cúldado infantil. (Bleiberg e col.1980; Popkin \& Solon, 1976; Popkin, 1980). McGuire \& Popkin (1988) estabelecem um esquema metodologico 
conhecido como "The zero-sum game", segundo o qual, as mulheres do terceiro mundo estariam envolvidas num sistema fechado onde o tempo ou a energia destinados a qualquer nova iniciativa teria que ser necessariamente desviado de alguma de suas outras atividades. Assim, a utilização de novas tecnologias, oportunidades de mercado de trabalho e mesmo de servicos sociais, requerem um dispendio de tempo, energia ou dinheiro tal, que os mesmos podem não estar disponíveis sem um prejuízo da sua saúde ou da saúde e segurança econômica de seus familiares.

Dentro do quadro trabalho/tempo/cuidado infantil, deve ser colocado também a importância da qualidade do substituto da mãe durante as suas horas de trabalho, seja ele indivíduo ou instituição. $\mathrm{Na}$ ausência de ou inacessibilidade a creches, os principais substitutos da mãe trabalhadora de baixa renda são os outros membros da familla. Muitas vezes, essa responsabilidade recai sobre outra criança havendo um conseqüente e óbvio prejuizo da qualidade deste cuidado (Shah,1978; Popkin,1980; Leslie,1989).

0 aleitamento materno é outro aspecto que, evidentemente, se inclui neste "complexo" trabalho/cuidado infantil. A relacão entre aleitamento e trabalho materno e seu impacto sobre a saúde e nutricão infantil é vista de forma contraditória na literatura. Multos estudos indicam que o trabalho produtivo da mulher é causa de desmame precoce ao lado da introducão de alimentação suplementar (Nerlove,1974; Nard1,1984; Chen e col.1979; Rea \& Cukier,1988; Rea \& Solimano,1980). Por outro lado, algumas 
revisơes sobre $\circ$ assunto concluem que $\circ$ trabalho materno não prejudica ou não é a razão principal para o não início da amamentação ou para $\circ$ desmame precoce (Van Esterick \& Greiner,1981; Leslie,1985). Em um estudo conduzido no Chile (Vial e col.1989), observou-se que filhos de mulheres trabalhadoras apresentavam melhor ganho de peso e que os efeitos do desmame precoce eram contrabalançados pelos incrementos na renda domiciliar, o que permitia un maior consumo de alimentos e um melhor acesso aos serviços de saúde.

En suma, a literatura nos mostra que a avaliação do impacto resultante da maior ou menor utilização destes dois recursos primários, tempo e renda, sobre o estado de saúde e nutrição infantil é, na verdade, um tanto complicada, uma vez que existem diversos fatores envolvidos na questăo. Qualquer leitura deste impacto exige a adequada ponderação das particularidades de cada contexto, incluindo aspectos especificos tais como: o numero de horás trabalhadas, o valor da renda, o tipo, localização e compatibilidade do trabalho com cuidados infantis, o número de filhos, e a substituição da mãe em termos qualitativos e quantitativos, seja através de individuo ou de instituição.

Mas, se um melhor delineamento do problema exige a análise de especificidades como as citadas acima, elas por si só também năo são suficientes. Como o "cuidar" envolve aspectos materiáis e humanos e preciso nå apenas quantifica-los mas tambem considerar a possivel existência de inter-relação entre eles. 
Uma abordagem pelo lado material ou dos insumos, ou seja da quantidade e qualidade de alimentos e outros bens básicos necessários a um bom estado de nutrição e saúde, exigiria examinar as mães que desempenham trabalho produtivo em duas categorias: aquelas enquadradas na condição de pobreza absoluta e que, portanto, trabalham por extrema necessidade econômica, e aquelas cujo trabalho faz parte da sua condição natural de cidadã ou está mais associado a interesses pessoais. Haveria de se acrescentar ainda a apreciação do acesso das mulheres à instrução formal, o que enriquece a análise do problema ao permitir "qualificar". o tempo disponivel ao cuidado infantil.

2.3. 0. papel da escolaridade materna

Inúmeras evidências indicam a existência de uma associação positiva entre o nível de escolaridade materna e o estado nutricional infantil, mesmo controlando-se o efeito da renda (Cochrane e col.,1980; Thomas e col.,1988; Cleland \& Ginneken,1988). Diversos mecantsmos permeiam esta associação, más - que se sabe e se pode colocar num primeiro momento é que eles se dão através da mediação dos cuidados infantis. Seria interessante relembrar aqui as intermediaços anteriormente citadas entre o cuidado infantil e os outros dols "grupos problema" da desnutrição: o "acesso ao alimento" a o "complexo 
desnutrição-infecção". Tais intermediaçбes ocorrem na medida em que a educação estaria qualificando a capacidade de cuidado infantil da mulher e esta por sua vez modulando o acesso ao alimento e a prevençã̃o de infecções.

Pessoas de maior nivel educacional usam de forma mais eficiente os recursos disponiveis tanto a nivel domiciliar como no trabalho (Leibowitz,1974; Welch,1970). Este tipo de constatação reforça os achados de Horwitz (1987) que indicam a educação primária e secundária como tendo sido elementos chave sobre o grau de eficiência e efetividade atingidos pelos sistemas de saúde do Chile, Costa Rica e Cuba. Neste sentido, já se constatou tambem que determinados incrementos de renda resultaram num maior impacto sobre o estado nutricional de crianças de mães alfabetizadas do que daquelas de mães analfabetas (Baraig1,1980). Observou-se ainda que a educação materna pode, até certo ponto, compensar a falta de acesso a serviços públicos de saúde e planejamento familiar (Rosenzweig \& Schultz,1982). Lindenbaum (1985) verificou, num estudo realizado em Bangladesh, que a principal diferença entre mães escolarizadas e analfabetas era que as primeiras davam uma maior importância à limpeza. Suas casas eram mais organizadas e limpas. 0 autor observou ainda que os livros escolares enfatisavam a necessidade de higiene e que as criancas matriculadas em escolas se destacariam dentro de suas aldeias pela limpeza incorporando um padrăo de comportamento com 6bvias implicaços para a formação das suas proprias famílias. 
No entanto, a contribuição da escolaridade materna para a saúde infantil transcende a simples adoção de hábitos de higiene doméstica ou pessoal. Num extenso estudo sobre a questão, Cleland \& Ginneken(1988) reforçam a existência de uma poderosa associação entre escolaridade materna e sobrevivência infantil, mas ao revisar hipóteses e mecanismos sugeridos, não conseguem elucidar os caminhos envolvidos no processo.

Conforme observação de Boltanski (1979), embora a medicina não seja propriamente o objeto de um ensinamento, mesmo que sumário, na escola primária, a introduçăo de temas de ciências naturais e de higiene tem como resultado pelo menos a certeza de que existe nessa matéria um conhecimento verdadeiro e único, aquele que a escola detém e transmite. Além disso, argumenta o autor, do conjunto de atitudes mentais que são transmitidas pela escola, a mais essencial e mais velada talvez seja a própria intenção intelectual, ou seja, "a 1déia de que não existe nada que não possa ser objeto de uma interrogação crítica e tornar-se objeto de um conhecimento racional".

Assim, os mecanismos através dos quais o nível educacional materno contribui para a melhoria dos padrões de nutrição infantil passariam năo só pelo maior volume de informações objetivas adquiridas, mas por possiveis diferenciacôes em torno das suas concepç6es de mundo e sociedade; desta forma, a educação promoveria uma mudança de atitudes da mulher tanto em relaçăo ao 
mundo exterior, como em relação aos membros do domicílio fazendo inclusive com que suas atenções se tornem mais centradas nas necessidades da criança, sejam elas físicas ou psicologicas.

Em um trabalho histórico sobre os determinantes da mortalidade infantil, Caldwell(1979) conclui que as mulheres de maior nivel educacional encontram maior sucesso no "cuidar" infantil. Com base em pesquisa empírica realizada na Nigéria e seguindo uma visão teórica baseada na teoria da modernização, o autor sugere alguns mecanismos básicos através dos quais se dariam as intermediaçס̃es entre a educação materna $e$ as suas atitudes em relação à família; estes poderiam ser sumarizados da seguinte maneira:

- A educação promoveria a quebra de tradiçóes e crenças relativas a doenças, propiciando a adoção de outras alternativas de cuidados e terapias disponiveis.

- A mulher mais instruída teria uma maior capacidade de manipular o mundo moderno, procurando e reivindicando pelos serviços de saúde; além de ter uma maior facilidade para entender as explicaçôes fornecidas e aplicá-las corretamente.

- A educação da mulher promoveria uma profunda mudança nas relaçסes de autoridade dentro da familia, conferindo à mulher uma maior autonomia que seria utilizada em beneficio dos cuidados infantis. 
Desta maneira, a educação propiciaria condições para que a mãe estivesse mais alerta aos primeiros sinais de doença e procurasse atenção médica. Da mesma forma, ela estaria mais consciente sobre a importância de levar as crianças a visitas regulares ao serviço de saúde para imunização e outros acompanhamentos. Estaria ainda, mais apta a respeitar procedimentos mínimos de higiene fundamentais para a prevençăo de infecções, e mais apta para o adequado preparo e administraçăo da alimentaçăo infantil.

A terceira explicação fornecida por Caldwell se relaciona com o comportamento da mulher em relação aos outros membros do domicílio. A distribuição dos recursos do domicílio é feita em função da percepção das necessidades individuais. Esta percepção seria formada a partir de julgamentos sobre características individuais tais como o tamanho, idade, atividade, ciclo de vida (gravidez, lactação, menstruação, menopausa), além de crenças sobre capacidade digestiva e gostos individuais. Os padróes de distribuição de alimentos podem ser, ainda, baseados nos valores sociais e econômicos atribuidos aos membros do domicilio (Kumar, 1983; Chaudhury, 1988).

Considerando estes pressupostos pode-se dizer que, em se tratando de estado nutricional, a pobreza năo afeta todos os membros do domicilio de forma uniforme e que um dos ingredientechave na causalidade desta desigualdade é o processo de tomada 
de decisăo dentro do domicilio (Piwoz \& Viteri, 1985). Na medida em que o nivel de escolaridade materna afeta as relaçơes de autoridade, conferindo à mulher uma maior independência e um maior poder de decisão sobre as questões domiciliares, incluindo - controle dos recursos econômicos, ela tem o poder de contribuir positivamente para uma nova ponderação na distribuição de alimentos e cuidados aos membros do domicílio. Verificamos, portanto, mais uma vez o papel da educação agindo por intermédio do cuidado infantil sobre o "acesso ao alimento", entendido aqui como uma questão de distribuição intra-domiciliar de alimentos.

As hipoteses formuladas por Caldwell (1979) enfatizam o papel da educação formal como veículo de transformações culturais. Nesse sentido, a extensão do papel transformador da educação dependeria, por um lado, da herança cultural trazida pelos alunos e, por outro, do tipo de educação recebida, pois estes fatores podem implicar efeitos diferenciados sobre a saúde. Assim, observou-se, através da Pesquisa Mundial de Fecundidade da Nigéria (United Nations, 1985a), que os filhos de mães que receberam alguma educação formal nos moldes ocidentais apresentavam uma mortalidade $31,8 \%$ inferior à média. Por outro lado, os filhos de mães que receberam apenas uma instrução conforme os princípios do Corão registraram uma mortalidade 56,4\% acima da média. 0 próprio Caldwell $(1985,1986)$ enfatiza, em trabalhos posteriores, a importancia da religião sobre o estado de saúde infantil, notando que praticamente todos os paises do mundo com nívels de mortalidade muito altos em comparação com seu 
produto nacional per capita possuem uma tradicão cultural muçulmana. Já, muitos dos países no terceiro mundo com níveis de mortalidade relativamente baixos são de tradição budista ou hindu, religióes que dăo mais importancia à educação, inclusive das mulheres.

Esta interpretacão culturalista que atribui o efeito da escolaridade dos pais sobre o estado de saúde infantil à absorção de valores e comportamentos é parcialmente questionada por Simons(1992). 0 autor enfatiza a importância de variaçóes culturais e sub-culturais na forma de distintas atitudes e práticas sobre a contribuicão materna para a sobrevivência infantil e conclui que o efeito direto da escolaridade materna sobre a sobrevivência infantil consiste numa visão frequientemente exagerada. 0 mais provável para o autor é que a duração da escolaridade materna seja um fator de seleção, sendo que as atitudes maternas dirigidas ao bem estar infantil são adquiridas através da familia e características de sua cultura e subcultura. Esta questão será retomada mais adiante no capitulo 7 .

\subsection{Marco conceitual}

Numa tentativa de melhor visualizar a inserçăo do cuidado infantil e a participação da mulher na rede causal da desnutriçăo, apresentamos abaixo dois modelos que agmupam os 
processos envolvidos no aparecimento da doença. Tais modelos têm como objetivo destacar marcos causais sobre os quais se assentarão as hipóteses deste trabalho.

A figura 1 representa uma simplificação dos modelos tradicionais (Jonsson, 1981; Beghin, 1988) da desnutrição infantil, dando ênfase, no entanto, à centralidade do cuidado infantil, que, ao lado da renda e da disponibilidade de serviços, determinam o acesso ao alimento e o estado de saúde (prevenção de infecções). Estes dois áltimos fatores, conforme vimos na introdução deste trabalho, configuram "grupos-problema" que seriam modulados pelas ações da mulher, incluindo sua capacidade de cuidar adequadamente da criança.

0 segundo modelo (figura 2) fol desenhado numa tentativa de sistematizar os fatores e caminhos que determinam o cuidado infantil. Uma criança nascida numa condição de extrema pobreza é penalizada, de início, pela estmutura econômica e social. Sem condiçres materiais mínimas, quer seja a nivel de domicilio ou de servicos mais imediatos como os de saúde e saneamento, é muito pouco provável que está criança tenha saúde, sendo que ainda é grande e inaceitável o número de crianças que, devido a estas condições, não sobreviverão ao primeiro ano de vida.

No entanto, a partir de uma renda minima que garanta $\circ$ suprimento de bens materiais e de consumo minimamente necessários à sobrevivência, o estado de saúde infantil estará sendo 
determinado pela forma de condução dos culdados dirigidos à criança. Assim, a otimização do uso de um determinado serviço de saúde dependerá não apenas da sua acessibilidade física, mas, principalmente, da compreensão da sua importância por parte da mãe da criança, o que estimularia a procura do serviço. 0 grau de escolaridade, na medida em que promoveria uma conscientizaçåo das mães acerca dos processos envolvidos na etiologla das doenças, além de supostamente promover uma melhorla da percepcão das próprias doenças, estaria propiciando a aproximação desta criança ao serviço, ao mesmo tempo em que aumentaria as probabilidades de êxito em relação às orlentações fornecidas.

Por um lado, esta procura e utilizaçăo de serviços de saúde estaria influenciando as práticas alimentares infantis incluindo a decisão sobre o tempo do aleitamento materno, as práticas de higlene doméstica e pessoal e o manejo de infecçôes. Por outro lado, ela é determinada pela autonomia e poder de decisão da mulher e associada a fatores culturais que, por sua vez, podem ser reforçados ou quebrados pela influência da escolaridade da mãe. A educação, quer seja pela via formal ou informal, ao tornar os individuos consumidores mais eficlentes da informaço (Thomas,1988), propictaria à mulher a posstbilidade de fazer uma escolha informada, com impacto relevante sobre decisరes relativas a uma melhor qualidade do cuidado infantil. Por este conjunto de fatores e mecanismos estaria perpassando o poder dos melos de comunicação quanto ao repasse de informaçes elementares e de 
campanhas especificas, como por exemplo a campanha da reidratação oral, do aleitamento materno, vacinações, e outras.

A falta de serviços de saneamento e água tratada poderia ser compensada como já foi mencionado, por exemplo, pela escolaridade materna. Ao mesmo tempo e no mesmo grau de importância, está o tempo disponível para a efetivação de um cuidado apropriado. Quer seja para a realização de tarefas a nível doméstico, ou para a procura de serviços, a disponibilidade de tempo vai depender em certa medida da estrutura familiar, ou seja, número de filhos, número e idade dos moradores do domicilio e estado marital, más dependerá muito também do status de trabalho da mãe. Mulheres trabalhadoras mais escolarizadas possivelmente conseguem remuneração suficiente para garantir um substituto mais adequado para o cuidado dos seus filhos. Por outro lado, esta condição gera na mulher uma maior consciência da sua cidadania, fato que a leva a criar demandas politicas. Se por um lado isto é positivo, porque ao reivindicar seus direitos contribui para o avanço da democracia e em última instância para o bem estar da criança, por outro, pode ser prejudicial ao exercicio da maternidade na medida em que poderia afasta-la da criança através de escolhas e comportamentos que vão contra o melhor cuidado infantil, tais como o uso de mamadeira ao invés da amamentação, uma maior dedicação ao trabalho em detrimento do cuidado dos seus filhos. Já os filhos de uma mãe trabalhadora de baixa renda seriam os mais prejudicados, pois não contariam com disponibilidade de 
tempo materno nem de recursos financeiros adequados; situação esta que seria agravada por um maior número de horas de trabalho.

Acompanhando a cadeia de eventos existentes entre a educação materna e o cuidado infantil, temos, de um lado, a renda familiar e, de outro, o controle de recursos pela mulher, que estariam fechando o quadro definidor do cuidado infantil. 


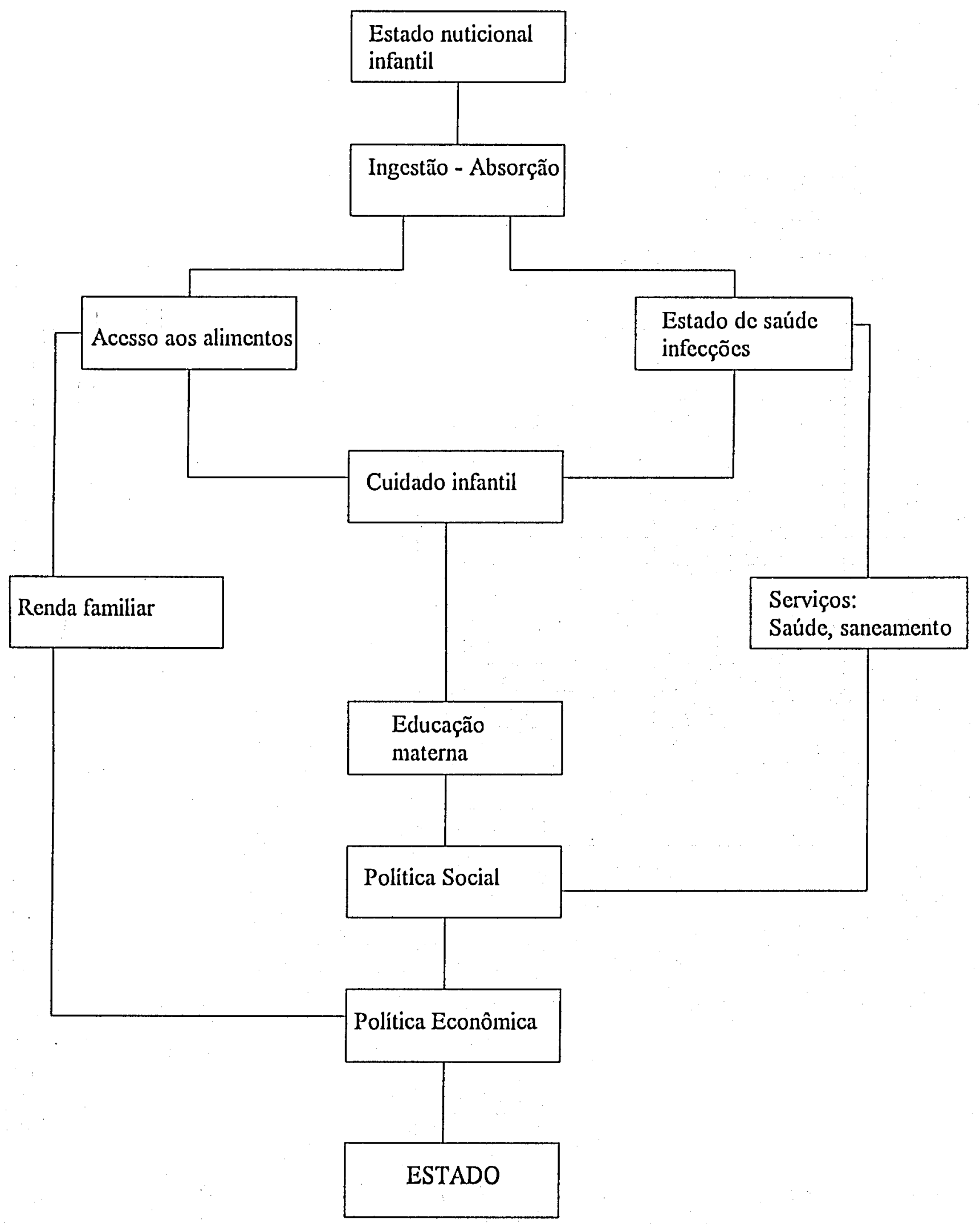




\section{Fìgura 2 Modelo de determinação do cuidado infantil}

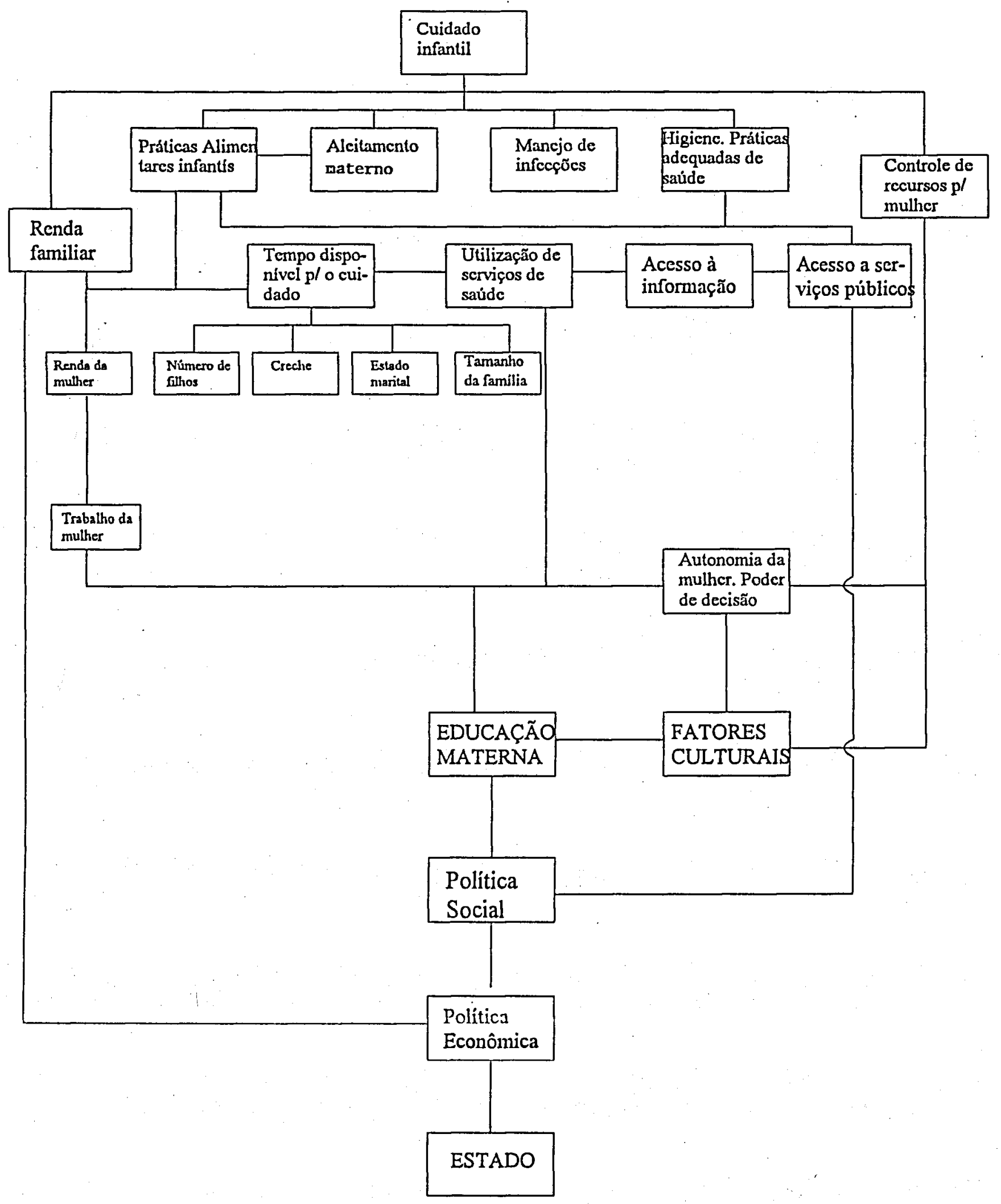


3. 0 "LOCUS" DO ESTUDO E A CONDIÇXO DA MULHER

\subsection{Diferenças regionais}

Se uma breve análise de alguns indicadores atestam com clareza os grandes contrastes sócio-econômicos existentes entre as Regiões Nordeste e Sul do Brasil, uma viagem através dos seus setores urbanos e murais mostra que há outros aspectos diferenciando as duas regióes. Entre estes, destacam-se as diferenças geográficas, climáticas, étnicas e principalmente culturais. Historicamente determinadas, as caracteristicas culturais destas regióes interagem de uma forma quase que simbiótica com o seu desenvolvimento sócio-económico.

Na Região Sul, por exemplo, o desenvolvimento econômico mais recente tem as suas raízes nos fluxos de imigrantes europeus não portugueses, ocorridos no século passado. A manutencão dos vínculos dos primeiros imigrantes artesãos com seus países de origem foi fundamental para a absorcão da nova tecnologia que iam conhecendo e colocando em prática no incipiente processo de industrialização que se iniciava. A instalação de pequenas oficinas artesanais de ferreiros deu origem a pequenas metalúrgicas, tendo muitas delas evoluido a ponto de apresentar ainda atualmente expressão econômica ná região (Furlanetto, 1990)1. No setor rural, os imigrantes foram se organizando numa agricultura de base familiar, onde os conhecimentios trazidos de seus antepassados europeus contribuíram 
significantemente para uma produçăo que excedia a agricultura de subsistência, dando origem a uma atividade comercial. A partir desta atividade foram geradas as condiçós para o surgimento de pequenas empresas industriais que beneficlavam a produço agropecuária ou fabricavam implementos essenciais à atividade agrária. Vale ressaltar que as condições climáticas e geográficas da regiåo favoreceram este desenvolvimento agroindustrial.

Já a historia do Nordeste mostra que embora a região tenha sido, no inf́cio da colonização, o centro do capitalismo mercantil brasileiro, a partir do século passado a sua economia entra em decadência. Nas outras regióes brasileiras a cultura do café e depois a industrialização produziram un grande diferencial de renda de maneira a transformar o Nordeste numa das regiões mais subdesenvolvidas do país. Tentativas de desenvolver o Nordeste, como por exemplo, a criação da SUDENE no final dos anos cinquienta, foram inviabilizadas por questões têcnicas e principalmente politicas. Estava claro, já nos anos 50 , que o desenvolvimento do Nordeste teria que passar não apenás pela industrialização, mas também pela reforma agrária. 0 modelo de industrializaça nordestino baseou-se numa tecnologia altamente capital intensiva $e$, consequentemente, incapaz de oferecer trabalho aos grandes contingentes de desempregados. Por outro lado, o grande desvio de recursos públicos carreados através de favorecimentos pessoais, obviamente contribuiu para frustrar os esforcos, tanto de industrializar a região, como de sanar um de seus graves problemas do setor mural: a seca. Além disso a tão 
necessária reforma agrária não foi realizada pois para isso seria preciso liquidar com o latifúndio mercantil ainda absolutamente dominante no Nordeste (Pereira, 1982).

Seguindo trajetórias tão diferentes não é de se estranhar que ao final da década de 80 , as duas regiões apresentassem enormes disparidades de ordem sócio-econômica. Se, na Região Sul - processo de desenvolvimento ancorou-se numa herança cultural e perpetuou-se através de uma estrutura agrária e industrial em expansãoz, no Nordeste, formas arcaicas de organização social e econômicas se sustentaram através de estruturas de poder que sobrevivem ainda hoje às custas da pobreza de grande parcela da população ${ }^{3}$.

Algumas análises mostram que, pelo menos em termos econômicos, expresso em forma de PIB regional, as desigualdades entre as regiões brasileiras teriam diminuído na década de 70 , em especial no periodo de 1970 a 1975, fase de aceleração do crescimento nacional4. No entanto, é importante ressaltar que num pais cuja distribuição de renda é brutalmente desigual, a utilização de dados tão agregados quanto o PIB, ou mesmo o PIB per capita, não reflete as verdadeiras condições de vida da população.

Indicadores de escolaridade e mortalidade infantil atestam que a qualidade de vida da população da Região Sul é incomparavelmente superior a da Região Nordeste. Pelos dados dá 
tabela 3.1 observa-se que a mortalidade infantil cai sensivelmente da década de 70 para o final da década de 80 nas duas regiões; no entanto, no Nordeste, em 1988, a taxa de mortalidade infantil ainda ê bastante alta em termos absolutos, sendo 2,6 maior que a da Região Sul para o mesmo ano. Situação semelhante ocorre com o analfabetismo, que em 1990, no Nordeste, ainda é 3,5 vezes superior ao valor encontrado para a Região Sul (tabela 2)

Tabela 1. Mortalidade Infantil. Regiões Nordeste e Sul do Brasil.1970 a 1988 .

\begin{tabular}{lrrc}
\hline Região & 1970 & 1980 & 1988 \\
Nordeste & 146,3 & 115,7 & 79,6 \\
Sul & 88,1 & 45,7 & 29,9
\end{tabular}

Fonte: FIBGE, Censo demográfico 1970; Oliveira,1993.

Tabela 2. Evolução das taxas de analfabetismo de 1970 para 1990 entre a população de maiores de 10 anos. Regiões Nordeste e Sul.

\begin{tabular}{lccc}
\hline Região & 1970 & 1980 & 1990 \\
& & & \\
Nordeste & 60,9 & 46,1 & 35,7 \\
Sul & 22,8 & 14,9 & 10,4
\end{tabular}

Fonte: FIBGE, Censos demográficos 1970 e 1980; FIBGE, Anuário estatistico 1992. 
3.2. A mulher brasileira nas décadas de 70 e 80 .

A análise do status da mulher nordestina e sulina nas décadas de 70 e 80 certamente não pode estar desvinculada do desenvolvimento econômico das suas regiões de origem. No entanto, é preciso situá-1o, mesmo que de forma breve, dentro do contexto mais amplo dos movimentos sociais da época.

Já em 1948 a Declaração dos Direitos Humanos das Naçóes Unidas e o Comitê para o status da mulher das Nações Unidas codificavam o ideal de direitos iguais para homens e mulheres; nas dêcadas que se seguiram foi ocorrendo gradualmente uma modificação nas atitudes, hábitos e mesmo na legislação em favor da mulher. O Ano Internacional da Mulher, as Conferências da Mulher no México em 1975 e em Copenhagen em 1980 foram eventos importantes. O ano de 1975 foi declarado como o Ano Internacional da Mulher "para ser orientado à ação intensificada de promoção da igualdade entre homens e mulheres, no sentido de garantir a total integração da mulher dentro dos esforços de desenvolvimento e para aumentar a contribuição da mulher no fortalecimento da paz mundial" (United Nations,1985b). o período de 1976-85 foi designado pelas Nações Unidas como a Década da Mulher cujo lema era: Igualdade, Desenvolvimento e Paz.

B inegável a importancia destas ações coordenadas em direçáo a emancipaçáo da mulher nas sociedades; no entanto, as 
verdadeiras conquistas só foram atingidas graças à organização das próprias mulheres através do movimento feminista. Por esta mesma razão, diferentes patamares de avanços foram conseguidos em diferentes países.

Os discursos e práticas feministas são herdeiros dos movimentos contestatórios dos anos $60 \mathrm{e}$, embora tenham se desdobrado em inúmeras vertentes, os princípios democráticos são marcas comuns a todos (Souza Lobo, 1991). No Brasil, em particular, o contexto político da época do surgimento do movimento feminista faz coincidir a luta das mulheres com as Iutas mais gerais pela redemocratização da sociedade. Este fato contribui para o fortalecimento dos grupos feministas que vão se organizando e ocupando espaços reivindicando, inclusive, ao nível do legislativo a igualdade de direitos.

A Constituição de 1988 é uma das mais avançadas do mundo, em termos de direitos da mulher (Brasil,1988). Nela encontram-se garantidos direitos fundamentais, como por exemplo, a "proibicăo de diferença de salários, de exercício de funçoes e de critério de admissão por motivo de sexo, ldade, cor ou estado civil"(art. 7 ;incisoXXX) . Com relação a maternidade no quadro do trabalho, fica garantida a "licença a gestante sem prejuizo do emprego e do salário, com a duração de cento e vinte dias" (art.7;XVIII). A constituiç্রিo preve ainda no capitulo dos direitos sociais "assistencia gratuita aos filhos e dependentes 
desde o nascimento até seis anos de idade, em creches e préescolas" (art.7,XXV).

Infelizmente, a nível institucional, o país não alcançou o nivel de avanço proposto pela sua própria sociedade, e o que se assiste ainda hoje é, apesar dos princípios da Carta Magna, a existência de discriminações elementares contra a mulher; sendo uma das mais comuns a desigualdade salarial em relação ao homem. Conforme observa Lewin (1980), esta desigualdade tende a ser menor nos níveis de instmacão mais baixos, talvez até pelo motivo de se tratar de salários já tão baixos que não comportam maior discriminação.

3.2.1. O trabalho e a educação das mulheres nas décadas de $1970 \mathrm{e}$ 1980

Nos anos setenta, a expansão da economia, o acelerado processo de industrialização e a crescente urbanização estabelecem as condições favoráveis a profundas transformações nos padrốes de consumo e de comportamento com conseqüentes mudanças dos valores relativos ao papel social da mulher. Essas transformações foram intensificadas pelo impacto dos movimentos feministas e pela presença feminina cada vez mais atuante nos espaços públicos (Souza-Lobo,1991). A expansăo da escolaridade e - maior acesso das mulheres às universidades contribuem para este processo de transformaçăo. A queda de fecundidade reduz o número 
de filhos, sobretudo nas cidades e regiöes mais desenvolvidas do país, liberando a mulher para o trabalho (Bmuschini,1989). A consolidação de tantas mudanças nos padrões de comportamento é um dos fatores que explicariam a persistência da atividade feminina na década de oitenta que, ao contrário da anterior, teve como marca registrada a crise econômica, a inflação e o desemprego. As taxas de atividade feminina praticamente dobram nas duas macroregiões de 1970 para 1990 (tabela 3).

Acompanhando a tendência da escolarização da população brasileira como um todo, os indicadores de escolaridade da mulher no periodo de 1970 a 1990 mostram uma melhora significante, qualquer que seja o indicador usado para as duas regiões, ou seja, analfabetismo ou 4 ou mais anos de estudo (tabelas 4 e 5).

Tabela 3. Taxas de atividade feminina. Regióes Nordeste e sul. 1970 a 1990.

\begin{tabular}{cccc}
\hline Regiăo & \multicolumn{3}{c}{ ano } \\
& 1970 & 1980 & 1990 \\
Nordeste & & & \\
Urbano & 18,6 & 25,9 & 36,3 \\
Rural & 22,7 & 30,3 & 37,7 \\
Sul Urbano & 15,1 & 20,6 & 34,0 \\
Uural & 21,6 & 31,7 & 43,9 \\
Rural & 26,1 & 36,5 & 41,8 \\
\hline
\end{tabular}

Fonte: FIBGE, Anuário Estatistico,1992. 
Tabela 4. - Mulheres Analfabetas de 25 a 29 anos (\%). Regiões Nordeste e Sul

\begin{tabular}{lccc}
\hline Região & \multicolumn{3}{c}{ ano } \\
& 1970 & 1980 & 1989 \\
Nordeste & 51,9 & 28,5 & 22,4 \\
Urbano & 32,9 & 23,1 & 15,2 \\
Rural & 67,3 & 55,1 & 35,8 \\
Sul Urbano & 23,4 & 11,0 & 5,8 \\
Rural & 12,9 & 7,9 & 5,2 \\
& 34,0 & 18,1 & 7,5 \\
\hline
\end{tabular}

Fonte: FIBGE, Censos demográficos 1970,1980; FIBGE, 1989.

Tabela 5. - Mulheres de 10 anos ou mais com 4 ou mais anos de estudo (\%). Regiões Nordeste e Sul.

\begin{tabular}{lccc}
\hline Região & & ano & \\
& 1970 & 1981 & 1990 \\
Nordeste & 19,3 & 32,6 & 42,6 \\
$\quad$ Urbano & 25,6 & 46,8 & 54,9 \\
Rural & 9,8 & 13,9 & 23,3 \\
Sul Urbano & & & \\
Urural & 36,7 & 57,4 & 66,0 \\
Rura, & 47,2 & 64,1 & 70,7 \\
& 23,9 & 45,2 & 55,6
\end{tabular}

Fonte: FIBGE, Censo demográfico 1970; FIBGE, Anuários Estatísticos 1981, 1992. 


\subsection{Considerações finais}

En suma, pelos dados apresentados, pode-se dizer que a população da Região Nordeste encontra-se ao final da década de 80 muito aquém do padrão de vida atingido pela população do Sul. B́ importante ressaltar ainda que, de acordo com os dados da PNSN, o Nordeste concentra $35 \%$ da população brasileira de menores de cinco anos, enquanto que a mediana da renda domiciliar per capita da sua população urbana é igual US $\$ 22,00$ e da população rural apenas US $\$ 10,01$ contra US\$ 55,60 e US $\$ 23,80$ respectivamente para as áreas urbana e mural da Região Sul. Com relação à utilização de serviços de saúde há indicações de que a Região Nordeste seria a mais prejudicada do país devido a baixá disponibilidade de serviços (Benício e col.1992). Devido aos mais baixos salários na Região Nordeste, a média dos rendimentos das mulheres é $36 \%$ menor que a média dos rendimentos da trabalhadora sulina (FIBGE, 1992).

Acompanhando a tendência de todos estes indicadores até aqui apresentados, o quadro da desnutrição infantil crônica nas regibes em estudo medido pela PNSN mostra que no Nordeste a prevalência da desnutriçăo é três vezes maior do que na Região Sul. Ou seja, nas áreas urbanas do Nordeste encontra-se $20,7 \%$ de desnutricåo contra $6,8 \%$ no Sul, e, nas áreas murais $29,4 \%$ contra $11,4 \%$ respectivamente. 
Notas

1. Seguindo o Sudeste, a região líder do país, o Sul representa hoje a segunda região industrial do país com $19,4 \%$ do emprego e $15,6 \%$ do valor das transformações industriais (Furlanetto,1990).

2. A Região Sul acrescenta-se a vantagem comparativa de encontrar-se diretamente ligada através de infra-estrutura de comunicação e pela complementaridade de suas atividades econômicas com as outras atividades produtivas concentradas em São Paulo e demais áreas urbanas da Região Sudeste (Ablas,1980).

3. Seguindo à tradicáo das teses cepalinas acerca do desenvolvimento do Terceiro Mundo, Miranda( 1979) enfatiza que no Brasil o desenvolvimento ocorreu em todas as regiões, mas em consequência das diferenças regionais, em termos de divisão do trabalho, algumas regiões tornaram-se mais desenvolvidas enquanto que outras permaneceram subdesenvolvidas.

4. De 1970 para 1980 o PIB regional aumenta de 537,7 para 1471,4 no nordeste e no Sul de 767,7 para 2087,6 (valores expressos em milhões de $\mathrm{Cr} \$$ ). Estes valores correspondem a uma porcentagem do PIB nacional igual a 11,98 para o Nordeste e 17,00 para o Sul; (Andrade 1989). 


\section{HIPOTESES E OBJETIVOS}

\subsection{Hipóteses a serem testadas}

O estado nutricional de pré-escolares está associado às seguintes características maternas e domiciliares:

- grau de escolaridade materna

- condição de trabalho da mãe

- número de filihos

- tamanho da familia

- número de moradores maiores de 10 anos de idade

- posse de televisão

- estado marital da mãe

- rendimentos maternos 


\subsection{Objetivos do estudo}

Geral

Avaliar nas Regiões Nordeste e Sul do Brasil a importância do papel desempenhado pelo cuidado infantil sobre a prevalência da desnutrição protéico-calórica em crianças menores de cinco anos.

Especificos

Verificar a existëncia de associação entre características maternas definidoras do cuidado infantil - escolaridade, condição de trabalho, rendimentos, número de filhos e estado marital - e prevalência da desnutrição em pré escolares.

Verificar a existência de associação entre caracteristicas familiares/domiciliares relacionadas ao cuidado infantil támanho da família, número de moradores maiores de 10 anos, acesso a informações - e prevalência da desnutrição em préescolares.

Quantificar o risco de desnutrição infantil associado a cada fator nos setores urbanos e rurais das Regiós Nordeste e Sul. 


\section{METODOLOGIA}

\subsection{Fonte de dados}

Este estudo foi realizado a partir de um inquérito nacional: a Pesquisa Nacional sobre Saúde e Nutrição (PNSN). A PNSN teve a sua coleta de dados realizada entre 3 de julho e 15 de setembro de 1989 por 498 equipes de campo entrevistando uma população de 63.213 pessoas; foram estudados 14.455 domicilios. A amostra da PNSN é estratificada e probabilística, fornecendo estimativas confiáveis sobre a população brasileira e suas caracteristicas em 1989. A pesquisa incluiu questões sobre emprego, renda, escolaridade, características do domicilio, saneamento, etc. Questionários especificos foram aplicados para crianças, mulheres em idade fértil, adolescentes e adultos, envolvendo práticas alimentares, utilização de serviços, histôria reprodutiva, morbidade e mortalidade. Tendo como objetivo principal o de avaliar o estado nutricional da população, baseado na análise das medidas antropométricas de peso e altura, todos os individuos residentes nos domicílios sorteados foram pesados e medidos. As equipes de entrevistadores receberam os seguintes instmumentos de medição:

- uma balança micro-eletrônica portátil, da marca nacional Filizola para pesar adultos e crianças, com precisão de 100 gr.; - uma régua antropométrica, de fabricacão nacional, para medir o comprimento de crianças pequenas até $100 \mathrm{~cm}$. , com precisão de $0,1 \mathrm{~cm}$.; 
- uma fita métrica, de fábricação francesa, para medir a altura de crianças maiores e de adultos, com precisão de $0,1 \mathrm{~cm}$. (INAN/IPEA/IBGE, 1988b).

\subsection{Amostra}

Neste estudo foram analisados os setores urbano e rural de duas das macro regiồes geográficas brasileiras: Região Nordeste e a Região Sul.

O banco de dados utilizado para este estudo foi obtido a partir do arquivo original da PNSN em computador de grande porte. Continha originalmente 3556 casos, que correspondiam ao numero total de crianças menores de cinco anos presentes na PNSN circunscritas às regiões Nordeste e Sul do país. A análise de consistência de dados ${ }^{2}$ eliminou vinte e sete casos e passou-se então a se trabalhar com 3529 casos distribuídos da seguinte maneira:
Nordeste Urbano $n=866$
Nordeste Rural $n=1258$
Sul Urbano $n=630$
Sul Rural $n=775$ 
5.3. Varí́veis em estudo.

\subsubsection{Variável dependente}

A prevalência da desnutrição infantil foi estimada, neste estudo, através do cômputo de crianças com indices altura/idade inferiores a menos dois escores $z$, ou seja, crianças com altura inferior a dois desvios-padrão, da mediana de peso prevista para sua idade e sexo. 0 cálculo dos índices antropométricos foi realizado através do padrão internacional de referência NCHS/OMS (Dibley,1987). O ponto de corte escolhido segue recomendações da Organização Mundial de Saúde (WHO,1986).

\subsubsection{Características maternas}

- Escolaridade (Escola)

De acordo com o grau de instrução, as mães de crianças de 0 a 59 meses foram agmupadas em três categorlas: analfabeta (incapaz de ler ou escrever un bilhete simples), 1 a 3 anos de estudo, e 4 ou mais anos de estudo.

- Trabalho (Horas)

A informação obtida a respeito do trabalho materno refere-se aos 15 dias anteriores a data da entrevista (INAN/IPEA/IBGE,1988a). A variável fol categorizada segundo 0 número de horas de trabalho semanals : 
Zero horas de trabalho (não trabalha), 1 a 30 horas de trabalho, 31 ou mais horas de trabalho.

- Renda (Renda materna)

Esta variável corresponde ao valor da renda proveniente do trabalho materno em atividades produtivas e foi classificada de acordo com o seu valor proporcional ao rendimento domiciliar total em três categorias: zero, 1 a $40 \%, 41$ a $100 \%$ da renda domiciliar.

- Estado marital (Marido)

Esta variável indica a presença de cônjuge no domicílio independente da sua situação legal.

- Número de filhos

O número de filhos foi agrupado de acordo com as seguintes faixas etárias, formando três variáveis distintas:

-Filhos de 0 a 5 anos incompletos (Menores): 1, 2 ou.+ -Filhos de 5 a 10 anos incompletos (Médios): 0, 1 ou + .

-Maiores de 10 anos (Maiores): 0,1 ou + .

5.3.3. Características do domicílio

- Número de pessoas na família (Moradores)

Número total de pessoas residindo no domicílio, excluindo-se agregados e pensionistas. 
- Lúmero de moradores maiores de 10 anos de idade. (Mor.>10 anos).

Corresponde ao número de moradores maiores de 10 anos, excluindo-se os agregados e pensionistas.

- Acesso à informação (TV)

Existência de televisão no domicílio.

- Renda domiciliar per capita (Tercil de renda nacional)

A renda domiciliar per capita corresponde aos rendimentos de todos os membros do domicilio expressos em US\$ dólares e divididos pelo número de moradores. A variável foi usada como variậvel de controle no estudo como um todo e, pará tanto, foi dividida em tercis.

- Idade da criança (Icriança)

A idade da criança foi utilizada como variável controle tendo sido categorizada em cinco grupos:

zero i- 12 meses, 12 i- 24 meses, 24 i- 36 meses, 36 i- 48 meses, $48 i-60$ meses de idade. 


\subsection{Analibe dos dados}

\subsubsection{Distribuiça e caracterizaçăo das variâveis}

As variáveis em estudo, em particular as variáveis discretas e categoricas, foram analisadas inicialmente atraves da distribuiço de frequencias absolutas e percentuais, verificando ainda a viabilidade de uso da variével em fungă da taxa de "ngo resposta". Mesmo nas variáveis onde o número de "não resposta"

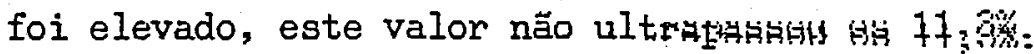

A seguir foi feita a categorização das variáveis utilizandose pontos de corte adotados na literatura. A distribuição de casos em cada categoria foi testada posteriormente através de uma tabulação cruzada entre cada uma das variáveis já categorizadas e a variável dependente, "desnutrição". Categorias com total de casos inferior a cinco foram submetidas a reagmupamentos de maneira a se evitar a não convergência de dados na análise de regressão logistica. Cortes semelhantes foram utilizados para categorizar as variâveis nas quatro regiões estudadas, de maneira a se permitir a comparabilidade dos resultados. Nesta etapa da análise utilizou-se os programas EPI INFO e SPSS PC+.

Apesar da relevância de algumas variáveis para este estudo tais como o acesso à creche, acesso à serviços de saúde e aleitamento materno, como foi colocado nos capitulos 
introdutorios deste trabalho, nåo fol possivel inclui-las na análise estatistica. A análise da variável creche foi inviabilizada devido ao baixo número de crianças menores de cinco anos freqüentando creche no país. Informações sobre aleitamento materno e acesso a serviços de saúde não puderam ser incluídos no estudo em função do tipo de delineamento da PNSN e da inadequação dos indicadores disponiveis no caso do acesso a serviços.

\subsubsection{Análise de regressão logística}

Na análise de regressão logística, assin como se fez desde as análises preliminares, trabalhou-se separadamente com os dados de cada região, chegando-se à construção de quatro modelos independentes.

A seleção de variáveis para a elaboração da modelagem foi feita através da análise univariada entre cada um dos fatores e a variável dependente (Hosmer \& Lemeshow 1989). Os cálculos dos odds ratios e os seus respectivos intervalos de confiança permitiram a discriminação das variáveis a serem incluídas no processo de modelagem, ou seja, aquelas que não mostravam associação com a desnutrição infantil eram descartadas já nesta etapa preliminar. Este procedimento também permitiu verificar a força de associação entre o fator em estudo e a variável dependente, de maneira a facilitar a decisão a respeito da ordem de entrada de varieveis no processo de modelagem. No capitulo 7 
serão apresentados os resultados desta análise preliminar para as quatro regiões em estudo (ver Tabelas $6,7,8$ e 9) e a relação de variáveis selecionadas para a modelagem (ver Quadro 1). É importante destacar aqui que embora, estejamos tratando de um estudo transversal, as medidas de odds ratio serão utilizadas como uma aproximação de medida de risco.

A análise de regressão logística foi realizada através do SPSS PC+ pelo método "enter" para modelo não condicional.

\subsubsection{Etapas da modelagem}

Para a seleção do melhor modelo utilizou-se o chamado "forward selection procedure" (Hosmer \& Lemeshow, 1989). Partiu-se de modelo contendo a variável que mostrou maior intensidade de associação com a desnutrição na análise univariada e a seguir foram sendo acrescentadas as demais variáveis, uma a uma. Após o acréscimo de cada variável no modelo, três ítens foram avaliados:

- a presença de significância estatística da nova variável (nível crítico inferior a 5\%) atravês da razão de verossimilhança deste modelo em relação ao modelo anterior sem esta variável (G).

-a importância da variável dentro do marco conceitual do estudo.

-a presença de efeito de confusão em relação às demais variáveis do modelo. 
A nova variavel permaneceu no modelo quando pelo menos uma das três situações acima foi identificada. No caso da presença de efeito de confusão, testou-se no modelo final a presença de efeito de interação. A significância de possíveis interações de interesse epidemiologico também fol testada, independentemente da detecção prêvia de efeito de confusão.

No processo de modelagem as variáveis de controle - tercil de renda per capita e idade da criança - foram introduzidas após a entrada dos fatores em estudo. Mais detalhes sobre as etapas da modelagem, bem como sobre o nummero de casos que entraram nos modelos de cada região encontram-se nos quadros 6 a 9 do anexo.

Nota

1. A análise de consistência do banco de dados incluiu a consistência de limites para o caso das variáveis continuas, e a consistência do índice antropométrico Altura/Idade, utilizado neste estudo. Esta última seguiu critério proposto por Monteiro,C.A. (Comunicação pessoal,1993), tendo sido efetuada através da diferença entre os indices Altura/Idade e Peso/Altura e do resultado desta operação, eliminados os casos com valores $<-6.00$ ou $>6.00$. 


\section{RESULTADOS}

\subsection{Análise univariada}

Os resultados obtidos através da análise univariada para cada uma das regiões estão apresentados nas tabelas $6,7,8$ e 9 .

Conforme mostram os dados, foram observadas elevadas prevalências de déficits nutricionais $A / I$ na maioria das variáveis/categorias da Região Nordeste, tanto no seu âmbito rural como urbano. A Região Sul, por outro lado, seja na área urbana ou rural, apresenta prevalências bastante mais baixas quando comparadas ao Nordeste. Estes resultados evidenciam assim as piores condições de vida da população nordestina. Observa-se que, variáveis como por exemplo, a escolaridade da mãe e posse de IV, mostram, na Região Nordeste, uma distribuição bem menos favorável ao bem estar infantil do que na Região Sul. Vale lembrar que as diferenciações observadas entre as distribuições das variáveis bem como nas prevalências de déficits de uma região para a outra, prochuziram valores de odds ratio de magnitudes bastantes diferentes.

0 grau de escolaridade materna bem como o nivel de renda familiar per capita encontram-se inversamente associados às prevalencias da desnutriçăo em todas as regiðes. 0 mesmó năo pode ser dito em relação às outras variáveis onde se observou variabilidade de resultados de uma regiăo a outra. 
A partir dos resultados dos odds ratios e da sua significância estatística, selecionaram-se os fatores de risco a serem estudados posteriormente na análise multivariada. As variáveis escolaridade da mãe, posse de TV, horas de trabalho, filhos menores de 5 anos, filhos de 5 a 10 anos, moradores, e moradores maiores de 10 anos mostraram-se estatisticamente significantes e foram selecionadas para o Nordeste Urbano e também para a o Nordeste Rural. O Sul Urbano ficou com a escolaridade da mãe, posse de TV, filhos menores de 5 anos, filhos de 5 a 10 anos, filhos maiores de 10 anos, e moradores, enquanto que no SuI Rural mantiveram-se estatisticamente significantes as variáveis escolaridade da mãe, posse de TV, horas de trabalho, filhos menores de 5 anos, filhos de 5 a 10 anos e moradores. As variáveis idade da criança e renda domiciliar per capita foram selecionadas para todas as regiôes, mesmo quando não se mostravam estatisticamente significantes, já que foram utilizadas como variáveis de controle. Estes resultados encontram-se sumarizados no quadro abaixo. 
Quadro 1 - VARIAVEIS SELECIONADAS PARA A ANALISE DE REGRESSAO LOGFSTICA POR REGIXO/SETOR DE ESTUDO.

\begin{tabular}{|c|c|c|c|}
\hline $\begin{array}{l}\text { NORD. URB. } \\
\text { variável }\end{array}$ & $\begin{array}{l}\text { NORD. RURAL } \\
\text { variâvel }\end{array}$ & $\begin{array}{l}\text { SUL URBANO } \\
\text { variável }\end{array}$ & $\begin{array}{l}\text { SUL RURAL } \\
\text { variável }\end{array}$ \\
\hline Escola & Escola & Escola & Escola \\
\hline Posse de TV & Posse de TV & Posse de TV & Posse de TV \\
\hline Horas & Horas & - & Horas \\
\hline Filhos $<5$ & Filhos $<5$ & Filhos $<5$ & Filhos $<5$ \\
\hline Filhos 5-10 & Filhos 5-10 & Filhos 5-10 & Filhos 5-10 \\
\hline - & - & Filhos $>10$ & - \\
\hline Moradores & Moradores & Moradores & Moradores \\
\hline Morad. $>10$ a. & Morad.>10 a. & - & - \\
\hline Icriança & Icriança & Icriança & Icrianca \\
\hline Renda & Renda & Renda & Renda \\
\hline
\end{tabular}


Tabela 6. DISTRIBUIÇX్ DA AMOSTRA SEGUNDO AS VARIAVEIS EM ESTUDO E SUA ASSOCIAÇZ̊O COM O DEFICIT DE ALTURA POR IDADE (A/I) . REGIXO NORDESTE URBANO. PNSN 1989.

\begin{tabular}{|c|c|c|c|}
\hline VARIAVVEL & $N$ & $\begin{array}{l}\text { PREVALENCIA } \\
\text { DO DEEICIT A/I }\end{array}$ & $\begin{array}{l}\text { ODDS RATIO } \\
\text { I.C. DE } 95 \%\end{array}$ \\
\hline $\begin{array}{l}\text { Escolaridade matern } \\
\text { analfabeta } \\
1-3 \text { anos } \\
4 \text { ou }+\end{array}$ & $\begin{array}{l}209 \\
104 \\
439\end{array}$ & $\begin{array}{l}40,7 \% \\
25,0 \% \\
11,6 \%\end{array}$ & $\begin{array}{l}\quad p=0.00000(*) \\
5,22(3,42-7,95) \\
2,54(1,44-4,45) \\
1,0\end{array}$ \\
\hline $\begin{array}{l}\text { Horas de trabalho } \\
30 \text { ou }+ \\
1-29 \\
0 \text { horas }\end{array}$ & $\begin{array}{l}238 \\
110 \\
501\end{array}$ & $\begin{array}{l}13,0 \% \\
29,0 \% \\
23,2 \%\end{array}$ & $\begin{array}{l}\quad p=0,00475 \\
0,50(0,32-0,78) \\
1,36(0,84-2,21) \\
1,0\end{array}$ \\
\hline $\begin{array}{l}\text { Posse de TV } \\
\text { não } \\
\text { sim }\end{array}$ & $\begin{array}{l}350 \\
495\end{array}$ & $\begin{array}{l}34,0 \% \\
11,9\end{array}$ & $\begin{array}{l}p=0,00000 \\
3,81(2,64-5,49) \\
1,0\end{array}$ \\
\hline $\begin{array}{l}\text { Filhos }<5 \text { anos } \\
2 \text { ou }+ \\
1\end{array}$ & $\begin{array}{l}425 \\
414\end{array}$ & $\begin{array}{l}27,2 \% \\
14 ; 7 \%\end{array}$ & $\begin{array}{l}\quad p=0,00001 \\
2,15(1,50-3,08) \\
1,0\end{array}$ \\
\hline $\begin{array}{l}\text { Filhos } 5 \text { a } 10 \text { anos } \\
1 \text { ou }+ \\
0\end{array}$ & $\begin{array}{l}501 \\
348\end{array}$ & $\begin{array}{l}27,1 \% \\
12,4 \%\end{array}$ & $\begin{array}{l}\quad p=0,00000 \\
2,64 \quad(1,79-3,92) \\
1,0\end{array}$ \\
\hline $\begin{array}{l}\text { Filhos }>10 \text { anos } \\
0 \\
1 \text { ou }+\end{array}$ & $\begin{array}{l}389 \\
460\end{array}$ & $\begin{array}{l}19,0 \% \\
22,8 \%\end{array}$ & $\begin{array}{l}p=0,17588 \\
0,79(0,56-1,12) \\
1,0\end{array}$ \\
\hline $\begin{array}{l}\text { Moradores } \\
7 \text { ou }+ \\
5-6 \\
2-4\end{array}$ & $\begin{array}{l}301 \\
309 \\
239\end{array}$ & $\begin{array}{l}48,0 \% \\
35,8 \% \\
12,1 \%\end{array}$ & $\begin{array}{l}\quad p=0,00000 \\
2,90(1,78-4,72) \\
1,89(1,15-3,13) \\
1,0\end{array}$ \\
\hline $\begin{array}{l}\text { Moradores }>10 \text { anos } \\
1-2 \\
3-4 \\
5 \text { ou }+\end{array}$ & $\begin{array}{l}341 \\
291 \\
217\end{array}$ & $\begin{array}{l}19,6 \% \\
18,6 \% \\
25,7 \%\end{array}$ & $\begin{array}{l}\quad p=0,07064 \\
1,07(0,71-1,63) \\
1,0 \\
1,60(1,03-2,49)\end{array}$ \\
\hline
\end{tabular}


Tabela 6 - continuaçào.

\begin{tabular}{|c|c|c|c|}
\hline $\begin{array}{l}\text { Estado marital } \\
\text { Sem companheiro } \\
\text { Com companheiro }\end{array}$ & $\begin{array}{l}145 \\
641\end{array}$ & $\begin{array}{l}17,2 \% \\
22,3\end{array}$ & $\begin{array}{l}p=0,17887 \\
0,73(0,44-1,19) \\
1,0\end{array}$ \\
\hline $\begin{array}{l}\text { Renda Materna } \\
0 \\
0,01-0,40 \\
0,41-1,00\end{array}$ & $\begin{array}{l}489 \\
220 \\
140\end{array}$ & $\begin{array}{l}23,1 \% \\
18,6 \% \\
17,9 \%\end{array}$ & $\begin{array}{l}\quad p=0.10889 \\
1,38(0,83-2,30) \\
0,95(0,53-1,70) \\
1,0\end{array}$ \\
\hline $\begin{array}{l}\text { Idade da } \\
\text { criança (meses) } \\
0-12 \\
12-24 \\
24-36 \\
36-48 \\
48-60\end{array}$ & $\begin{array}{l}137 \\
182 \\
158 \\
195 \\
177\end{array}$ & $\begin{array}{l}10,9 \% \\
24,7 \% \\
18,4 \% \\
22,1 \% \\
26,6 \%\end{array}$ & $\begin{array}{l}\quad p=0,00993 \\
0,34(0,17-0,67) \\
0,91(0,55-1,50) \\
0,62(0,36-1,08) \\
0,78(0,47-1,29) \\
1,0\end{array}$ \\
\hline $\begin{array}{l}\text { Tercil de Renda } \\
\text { Nacional } \\
10 \\
20 \\
3 \underline{0} .\end{array}$ & $\begin{array}{l}242 \\
274 \\
310\end{array}$ & $\begin{array}{r}34,3 \% \\
23,4 \% \\
8,1 \%\end{array}$ & $\begin{array}{l}5,95(3,57-9,99) \\
3,47(2,06-5,88) \\
1,0\end{array}$ \\
\hline
\end{tabular}

(*) Os valores de $p$ correspondem ao qui-quadrado de Pearson para as variáveis dicotômicas e ao qui-quadrado de tendência linear para as demais variáveis. 
Tabela 7. DISTRIBUIÇAO DA AMOSTRA SEGUNDO AS VARIAVEIS EM ESTUDO E SUA ASSOCIAÇAOO COM O DEFICIT DE ALTURA POR IDADE (A/I). REGIFO NORDESTE RURAL. PNSN 1989.

\begin{tabular}{|c|c|c|c|}
\hline VARIAVEL & $\mathbf{N}$ & $\begin{array}{l}\text { PREVALENCIA } \\
\text { DO DEEICIT A/I }\end{array}$ & $\begin{array}{l}\text { ODDS RATIO } \\
\text { I.C. DE } 95 \%\end{array}$ \\
\hline $\begin{array}{l}\text { Bscolaridade matern } \\
\text { analfabeta } \\
1-3 \text { anos } \\
4 \text { ou }+\end{array}$ & $\begin{array}{r}636 \\
285 \\
205\end{array}$ & $\begin{array}{l}37,3 \% \\
26,3 \% \\
15,1 \%\end{array}$ & $\begin{array}{l}\quad p=0.00000 \text { (*) } \\
3.33(2.16-5.16) \\
2,00(1,23-3.28) \\
1,0\end{array}$ \\
\hline $\begin{array}{l}\text { Horas de trabalho } \\
30 \text { ou }+ \\
1-29 \\
0 \text { horas }\end{array}$ & $\begin{array}{l}190 \\
145 \\
905\end{array}$ & $\begin{array}{l}42,1 \% \\
25,5 \% \\
28,0 \%\end{array}$ & $\begin{array}{l}\mathrm{p}=0,00074 \\
1,87(1,34-2,62) \\
0,88(0,58-1,34) \\
1,0\end{array}$ \\
\hline $\begin{array}{l}\text { Posse de TV } \\
\text { não } \\
\text { sim }\end{array}$ & $\begin{array}{r}1147 \\
92\end{array}$ & $\begin{array}{l}31,2 \% \\
13,0 \%\end{array}$ & $\begin{array}{l}p=0,00024 \\
3,02(1,58-5,92) \\
1,0\end{array}$ \\
\hline $\begin{array}{l}\text { No de filhos }<5 \text { an } \\
2 \text { ou }+ \\
1\end{array}$ & $\begin{array}{l}\text { nos } \\
843 \\
397\end{array}$ & $\begin{array}{l}32,9 \% \\
23,2 \%\end{array}$ & $\begin{array}{l}p=0,00043 \\
1,63(1,23-2,17) \\
1,0\end{array}$ \\
\hline $\begin{array}{l}\text { Filhos de } 5 \text { a } 10 \text { an } \\
1 \text { ou }+ \\
0\end{array}$ & $\begin{array}{l}108 \\
800 \\
440\end{array}$ & $\begin{array}{l}33,0 \% \\
24,1 \%\end{array}$ & $\begin{array}{l}p=0,00103 \\
1,55(1,18-2,04) \\
1,0\end{array}$ \\
\hline $\begin{array}{l}\text { Filhos }>10 \text { anos } \\
0 \\
1 \text { ou }+\end{array}$ & $\begin{array}{l}622 \\
618\end{array}$ & $\begin{array}{l}28,8 \% \\
30,9 \%\end{array}$ & $\begin{array}{l}p=0,41284 \\
0,90(0,70-1,16) \\
1,0\end{array}$ \\
\hline $\begin{array}{l}\text { Moradores } \\
7 \text { ou }+ \\
5-6 \\
2-4\end{array}$ & $\begin{array}{l}561 \\
376 \\
303\end{array}$ & $\begin{array}{l}36,4 \% \\
25,0 \% \\
23,8 \%\end{array}$ & $\begin{array}{l}p=0,00002 \\
1,83(1,32-2,55) \\
1,07(0,74-1,55) \\
1,0\end{array}$ \\
\hline $\begin{array}{l}\text { Moradores > } 10 \\
\begin{array}{l}1-2 \\
3-4 \\
5 \text { ou }+\end{array}\end{array}$ & $\begin{array}{l}571 \\
348 \\
321\end{array}$ & $\begin{array}{l}28,4 \% \\
27,3 \% \\
35,2 \%\end{array}$ & $\begin{array}{l}\quad p=0,05390 \\
1,05(0,77-1,44) \\
1,0 \\
1,45(1,03-2,04)\end{array}$ \\
\hline
\end{tabular}


Tabela 7 - continuação.

\begin{tabular}{|c|c|c|c|}
\hline $\begin{array}{l}\text { Estado marital } \\
\text { Sem companheiro } \\
\text { Com companheiro }\end{array}$ & $\begin{array}{r}103 \\
1058\end{array}$ & $\begin{array}{l}33,0 \% \\
30,0 \%\end{array}$ & $\begin{array}{l}p=0,52030 \\
1,15(0,73-1,81) \\
1,0\end{array}$ \\
\hline $\begin{array}{l}\text { Renda Materna } \\
0 \\
0,01-0,40 \\
0,41-1,00\end{array}$ & $\begin{array}{r}965 \\
186 \\
89\end{array}$ & $\begin{array}{l}27,6 \% \\
37,6 \% \\
38,2\end{array}$ & $\begin{array}{l}\quad p=0.00209 \\
0,62(0,38-1,00) \\
0,98(0,56-1,70) \\
1,0\end{array}$ \\
\hline $\begin{array}{l}\text { Idade da } \\
\text { criança (meses) } \\
0-12 \\
12-24 \\
24-36 \\
36-48 \\
48-60\end{array}$ & $\begin{array}{l}240 \\
286 \\
231 \\
228 \\
255\end{array}$ & $\begin{array}{l}15,0 \% \\
36,4 \% \\
26,0 \% \\
34,6 \% \\
35,7 \%\end{array}$ & $\begin{array}{l}0,32(0,20-0,50) \\
1,03(0,71-1,49) \\
0,65(0,42-0,95) \\
0,96(0,65-1,41) \\
1,0\end{array}$ \\
\hline $\begin{array}{l}\text { Tercil de Renda } \\
\text { Nacional } \\
10 \\
20 \\
30\end{array}$ & $\begin{array}{r}683 \\
397 \\
82\end{array}$ & $\begin{array}{r}35,9 \% \\
27,5 \% \\
3,7 \%\end{array}$ & $\begin{array}{cc}14,73 & (4,44-59,01) \\
9,97 & (2,96-40,38) \\
1,0 & \end{array}$ \\
\hline
\end{tabular}

(*) Os valores de $p$ correspondem ao qui-quadrado de Pearson para as variáveis dicotômicas e ao qui-quadrado de tendência linear para as demais variáveis. 
Tabela 8. DISTRIBUIÇช̧O DA AMOSTRA SEGUNDO AS VARIAVEIS EM ESTUDO B SUA ASSOCIAÇAO COM O DEFICIT DE ALTURA POR IDADE (A/I). REGIXO SUL URBANO. PNSN . 1989.

\begin{tabular}{|c|c|c|c|}
\hline VARIAVEL & $N$ & $\begin{array}{l}\text { PREVALENCIA } \\
\text { DO DEFICIT A/I }\end{array}$ & $\begin{array}{l}\text { ODDS RATIO } \\
\text { I.C. DE } 95 \%\end{array}$ \\
\hline $\begin{array}{l}\text { Escolaridade materna } \\
\text { analfabeta } \\
1-3 \text { anos } \\
4 \text { ou }+\end{array}$ & $\begin{array}{r}40 \\
101 \\
440\end{array}$ & $\begin{array}{r}25,0 \% \\
15,8 \% \\
3,4 \%\end{array}$ & $\begin{array}{l}p=0.00000(*) \\
9,44(3,58-24,75) \\
5,33(2,4-11,90) \\
1,0\end{array}$ \\
\hline $\begin{array}{l}\text { Horas de trabalho } \\
30 \text { ou }+ \\
1-29 \\
0 \text { horas }\end{array}$ & $\begin{array}{r}192 \\
62 \\
368\end{array}$ & $\begin{array}{l}6,3 \% \\
9,7 \% \\
6,8 \%\end{array}$ & $\begin{array}{l}p=0,88453 \\
0,91(0,42-1.95) \\
1,47(0,51-3,99) \\
1,0\end{array}$ \\
\hline $\begin{array}{l}\text { Posse de TV } \\
\text { não } \\
\text { sim }\end{array}$ & $\begin{array}{r}94 \\
527\end{array}$ & $\begin{array}{r}23,4 \% \\
4,0 \%\end{array}$ & $\begin{array}{l}p=0,00000 \\
7,36(3,68-14,75) \\
1,0\end{array}$ \\
\hline $\begin{array}{l}\text { Filhos }<5 \text { anos } \\
2 \text { ou }+ \\
1\end{array}$ & $\begin{array}{l}232 \\
389\end{array}$ & $\begin{array}{l}9,1 \% \\
5,7 \%\end{array}$ & $\begin{array}{l}p=0,10680 \\
1,66(0,85-3,22) \\
1,0\end{array}$ \\
\hline $\begin{array}{l}\text { Filhos de } 5 \text { a } 10 \text { anc } \\
1 \text { ou }+ \\
0\end{array}$ & $\begin{array}{l}08 \\
304 \\
318\end{array}$ & $\begin{array}{l}8,9 \% \\
5,0 \%\end{array}$ & $\begin{array}{l}\quad p=0,05847 \\
1,84(0,93-3,66) \\
1,0\end{array}$ \\
\hline $\begin{array}{l}\text { Filhos }>10 \text { anos } \\
0 \\
1 \text { ou }+\end{array}$ & $\begin{array}{l}358 \\
264\end{array}$ & $\begin{array}{r}4,5 \% \\
10,2 \%\end{array}$ & $\begin{array}{l}\quad p=0,00514 \\
0,41(0,21-0,81) \\
1,0\end{array}$ \\
\hline $\begin{array}{l}\text { Moradores } \\
7 \text { ou }+ \\
5-6 \\
2-4\end{array}$ & $\begin{array}{l}128 \\
201 \\
293\end{array}$ & $\begin{array}{r}12,5 \% \\
7,0 \% \\
4,4 \%\end{array}$ & $\begin{array}{l}\quad p=0,00348 \\
3,08(1,35-7,05) \\
1,61(0,70-3,74) \\
1,0\end{array}$ \\
\hline $\begin{array}{l}\text { Moradores > } 10 \text { anos } \\
\begin{array}{l}1-2 \\
3-4 \\
5 \text { ou }+\end{array}\end{array}$ & $\begin{array}{r}331 \\
19 \\
7\end{array}$ & $\begin{array}{l}5,1 \% \\
9,3 \% \\
8,2 \%\end{array}$ & $\begin{array}{l}P=0,12524 \\
0,53(0,25-1,11) \\
1,0 \\
0,88(0,34-2,24)\end{array}$ \\
\hline
\end{tabular}


Tabela 8 - continuação.

\begin{tabular}{|c|c|c|c|}
\hline $\begin{array}{l}\text { Estado marital } \\
\text { Sem companheiro } \\
\text { Com compamheiro }\end{array}$ & $\begin{array}{r}74 \\
525\end{array}$ & $\begin{array}{l}8,1 \% \\
6,7 \%\end{array}$ & $\begin{array}{l}\quad p=0,64571 \\
1,24 \quad(0,45-3,22) \\
1,0\end{array}$ \\
\hline $\begin{array}{l}\text { Renda Materna } \\
0 \\
0,01-0,40 \\
0,41-1,00\end{array}$ & $\begin{array}{r}361 \\
182 \\
79\end{array}$ & $\begin{array}{l}6,6 \% \\
7,1 \% \\
7,6 \%\end{array}$ & $\begin{array}{l}\quad p=0.73888 \\
0,87(0,32-2,46) \\
0,94(0,32-2,89) \\
1,0\end{array}$ \\
\hline $\begin{array}{l}\text { Idade da criança } \\
\text { (meses) } \\
0-12 \\
12-24 \\
24-36 \\
36-48 \\
48-60\end{array}$ & $\begin{array}{l}116 \\
127 \\
128 \\
126 \\
125\end{array}$ & $\begin{array}{l}9,5 \% \\
4,7 \% \\
3,9 \% \\
7,9 \% \\
8,8 \%\end{array}$ & $\begin{array}{l}1,09(0,42-2,83) \\
0,51(0,16-1,57) \\
0,42(0,12-1,36) \\
0,89(0,34-2,37) \\
1,0\end{array}$ \\
\hline $\begin{array}{l}\text { Tercil de Renda } \\
\text { Nacional } \\
10 \\
20 \\
30\end{array}$ & $\begin{array}{r}39 \\
127 \\
451\end{array}$ & $\begin{array}{r}23,1 \% \\
13,4 \% \\
3,8 \%\end{array}$ & $\begin{array}{l}7,66(2,8-20,26) \\
3,95(1,85-8,42) \\
1,0\end{array}$ \\
\hline
\end{tabular}

(*) Os valores de $p$ correspondem ao qui-quadrado de Pearson para as variáveis dicotômicas e ao qui-quadrado de tendência linear para as demais variáveis. 
Tabela 9. DISTRIBUIÇAO DA AMOSTRA SEGUNDO AS VARIÁVEIS EM ESTUDO E SUA ASSOCIAÇXO COM O DEFICIT DE ALTURA POR IDADE (A/I). REGIXO SUL RURAL. PNSN 1989.

\begin{tabular}{|c|c|c|c|}
\hline VARIÁVEL & $N$ & $\begin{array}{l}\text { PREVALENCIA } \\
\text { DO DEFICIT A/I }\end{array}$ & $\begin{array}{l}\text { ODDS RATIO } \\
\text { I.C. DE } 95 \%\end{array}$ \\
\hline $\begin{array}{l}\text { Escolaridade materna } \\
\text { analfabeta } \\
1-3 \text { anos } \\
4 \text { ou }+\end{array}$ & $\begin{array}{l}141 \\
201 \\
393\end{array}$ & $\begin{array}{r}29,1 \% \\
13,4 \% \\
4,3 \%\end{array}$ & $\begin{array}{l}\quad p=0.00000(*) \\
9,07(4,76-17,42) \\
3,43(1,75-6,78) \\
1,0\end{array}$ \\
\hline $\begin{array}{l}\text { Horas de trabalho } \\
30 \text { ou }+ \\
1-29 \\
0 \text { horas }\end{array}$ & $\begin{array}{r}224 \\
70 \\
471\end{array}$ & $\begin{array}{r}6,7 \% \\
11,4 \% \\
13,8 \%\end{array}$ & $\begin{array}{l}\quad p=0,00641 \\
0,45(0,24-0,83) \\
0,81(0,34-1,84) \\
1,0\end{array}$ \\
\hline $\begin{array}{l}\text { Posse de TV } \\
\text { não } \\
\text { sim }\end{array}$ & $\begin{array}{l}409 \\
351\end{array}$ & $\begin{array}{r}16,6 \% \\
5,1 \%\end{array}$ & $\begin{array}{l}\quad p=0,00000 \\
3,69(2,09-6,58) \\
1,0\end{array}$ \\
\hline $\begin{array}{l}\text { Filhos }<5 \text { anos } \\
2 \text { ou }+ \\
1\end{array}$ & $\begin{array}{l}356 \\
408\end{array}$ & $\begin{array}{r}16,0 \% \\
7,6 \%\end{array}$ & $\begin{array}{l}\quad p=0,00027 \\
2,32(1,43-3,78) \\
1,0\end{array}$ \\
\hline $\begin{array}{l}\text { Filhos de } 5 \text { a } 10 \text { ano } \\
1 \text { ou }+ \\
0\end{array}$ & $\begin{array}{l}0 s \\
419 \\
346\end{array}$ & $\begin{array}{r}13,4 \% \\
9,2 \%\end{array}$ & $\begin{array}{l}p=0,07570 \\
1,51(0,93-2,46) \\
1,0\end{array}$ \\
\hline $\begin{array}{l}\text { Filhos > } 10 \text { anos } \\
0 \\
1 \text { ou }+\end{array}$ & $\begin{array}{l}424 \\
341\end{array}$ & $\begin{array}{l}10,1 \% \\
13,2 \%\end{array}$ & $\begin{array}{l}p=0,18806 \\
0,74(0,46-1,19) \\
1,0\end{array}$ \\
\hline $\begin{array}{l}\text { Moradores } \\
7 \text { ou }+ \\
5-6 \\
2-4\end{array}$ & $\begin{array}{l}192 \\
291 \\
282\end{array}$ & $\begin{array}{r}18,8 \% \\
9,3 \% \\
8,9 \%\end{array}$ & $\begin{array}{l}\quad p=0,00189 \\
2,37(1,33-4,25) \\
1,05(0,57-1,93) \\
1,0\end{array}$ \\
\hline $\begin{array}{l}\text { Moradores > } 10 \text { anos } \\
1-2 \\
3-4 \\
5 \text { ou }+\end{array}$ & $\begin{array}{l}384 \\
262 \\
119\end{array}$ & $\begin{array}{l}10,4 \% \\
11,8 \% \\
14,3 \%\end{array}$ & $\begin{array}{l}\quad p=0,24771 \\
0,87(0,51-1,47) \\
1,0 \\
1,24(0,63-2,45)\end{array}$ \\
\hline
\end{tabular}


Tabela 9 - continuação.

\begin{tabular}{|c|c|c|c|}
\hline $\begin{array}{l}\text { Estado marital } \\
\text { Sem companheiro } \\
\text { Com companheiro }\end{array}$ & $\begin{array}{r}35 \\
708\end{array}$ & $\begin{array}{l}11,4 \% \\
11,4 \%\end{array}$ & $\begin{array}{l}\mathrm{p}=0,99824 \\
1,0(0,29-3,07) \\
1,0\end{array}$ \\
\hline $\begin{array}{l}\text { Renda Materna } \\
0 \\
0,01-0,40 \\
0,41-1,00\end{array}$ & $\begin{array}{r}633 \\
82 \\
50\end{array}$ & $\begin{array}{r}12,2 \% \\
11,0 \% \\
4,0 \%\end{array}$ & $\begin{array}{l}\mathrm{p}=0.10765 \\
3,32(0,77-20,18) \\
2,96(0,56-20,79) \\
1,0\end{array}$ \\
\hline $\begin{array}{l}\text { Idade da crianca } \\
\text { (meses) } \\
0-12 \\
12-24 \\
24-36 \\
36-48 \\
48-60\end{array}$ & $\begin{array}{l}130 \\
177 \\
137 \\
168 \\
153\end{array}$ & $\begin{array}{r}10,0 \% \\
12,4 \% \\
5,8 \% \\
11,9 \% \\
16,3 \%\end{array}$ & $\begin{array}{l}\quad p=0,14790 \\
0,57(0,26-1,22) \\
0,73(0,37-1,41) \\
0,32(0,13-0,77) \\
0,69(0,35-1,36) \\
1,0\end{array}$ \\
\hline $\begin{array}{l}\text { Tercil Renda } \\
\text { Nacional } \\
10 \\
20 \\
30\end{array}$ & $\begin{array}{l}159 \\
322 \\
277\end{array}$ & $\begin{array}{r}23,3 \% \\
12,7 \% \\
3,2 \%\end{array}$ & $\begin{array}{l}9,03(4,03-20,81) \\
4,34(1,99-9,80) \\
1,0\end{array}$ \\
\hline
\end{tabular}

(*) Os valores de $\mathrm{p}$ correspondem ao qui-quadrado de Pearson para as variáveis dicotômicas e ao qui-quadrado de tendência linear para as demais variáveis. 


\subsection{Análise de regressão logistica}

Os resultados da análise de regressão logistica para as distintas regiōes encontram-se apresentados nos quadros $2,3,4$, e 5 abaixo.

No Nordeste Urbano; o risco de mulheres analfabetas terem filhos desnutridos é alto, equivalendo a 2,89 quando comparado à categoria basal que corresponde a 4 ou mais anos de estudo. Destaca-se ainda o risco de 2,16 para crianças que residem em domicilios sem TV e de 2,08 quando as mães têm 1 ou mais filhos de 5 a 10 anos se comparadas com aquelas que não possuem nenhum filho nessa faixa etária. Mães que trabalham 30 ou mais horas por semana estão oferecendo proteção contra a desnutrição de seus filhos menores de cinco anos (odds ratio $=0,45$ ); 0 mesmo não acontece quando o número de horas de trabalho é inferior a 30 horas semanais.

No setor rural da Região Nordeste, o papel da escolaridade materna se estende para as mães de baixa escolaridade; assim 0 analfabetismo materno se configura num risco de 2,53 para a desnutriçåo infantil, enquanto que 1 a 3 anos de escolaridade mostra um risco de 1,66 vezes, ambos em relação a categoria mães com 4 ou mais anos de estudo. Interessante notar a direção oposta do risco associado ao trabalho materno, ou seja, trabalhar 30 ou mais horas corresponde a risco (odds ratio $=1,95$ ) e não proteção 
como no caso do contexto urbano. Na área mural, ter dois ou mais filhos de 0 a 5 anos produz um odds ratio de 1,65 em relaçáo a condição de se ter apenas um filho nesta faixa etária.

No Sul, no nivel urbano, o risco mais expressivo foi, assim como nas demais regiões, o do analfabetismo materno (odds ratio = 5,23). Escolaridade de 1 a 3 anos também é fator de risco no sul Urbano correspondendo a 2,89 em relação a níveis de escolaridade mais altos. A presenca de dois ou mais filhos na faixa etária de 0 a 5 anos está associada a um risco de 4,3, se comparada a existência na família, de um único filho. Não possuir TV equivale a um risco de 3,61 .

Viver no Sul Rural representa uma situação de risco semelhante aquela observada para as áreas urbanas da região, ou seja, não muda substancialmente a situação de risco de desnutrição para as crianças de mães analfabetas (odds ratio = 5,51 ) e de baixa escolaridade (odds ratio $=2,26$ ), se comparadas com as mães de 4 ou mais anos de estudo. O trabalho materno acima de 30 horas, no entanto, E proteção, diminuindo em $50 \%$ as chances de un filho destas mães ser desnutrido, se comparado com mulheres que trabalham um menor número de horas.

As variáveis de controle, tercil de renda per capita e idade da crianç, foram incorporadas aos modelos de cada regiăo. 0 tercil de renda per capita foi mantido nos modelos dos quatro setores, mesmo quando não se mostrava estatisticámente 
significante $(p>0,05)$. Optou-se por mantê-lo, como forma de ajuste, devido à grande discrepância existente entre a condição econômica das familias nas diferentes regiôes. A idade da criança foi mantida apenas onde se mostrava ser variável de confusão ou onde contribuia significantemente $(p<0,05)$ para o ajuste do modelo. Este foi o caso da Região Nordeste, tanto no setor urbano como no rural.

Quadro 2 - Modelo de regressão logística. Nordeste Urbano.

\begin{tabular}{lllll}
\hline Variável & Categoria & O.R. & I.C. & p \\
\hline Escola & & & & 0,0001 \\
& Analfabeta & 2,89 & $(1,80-4,66)$ & 0,0000 \\
1 a 3 anos & 1,73 & $(0,96-3,13)$ & 0,0662 \\
4 ou + & 1 & &
\end{tabular}

Horas

$\begin{array}{lllll}30 \text { ou }+ & & & & 0,0004 \\ 1 \text { a } 29 \text { horas } & 0,45 & (0,27-0,75) & 0,0024 \\ 0 \text { horas } & 1,59 & (0,62-2,76) & 0,0958 \\ & 1 & & & \\ \text { Não possui } & 2,16 & (1,37-3,40) & & 0,0009 \\ \text { Possui } & 1 & & & \end{array}$

$\begin{array}{lllll}\text { Filhos } & 1 \text { ou }+ & 2,08 & (1,38-3,13) & 0,0004 \\ 5 \text { a } 10 & 0 & 1 & \end{array}$

* Valores de odds ratio ajustados pela renda expressa em tercis e idade da criança 
Quadro 3 - Modelo de regressão logistica. Nordeste Rural.

\begin{tabular}{lllll}
\hline Variável & Categoria & O.R. & I.C. & P \\
\hline Escola & Analfabeta & 2,53 & $(1,62-3,96)$ & 0,0001 \\
& 1 a 3 anos & 1,66 & $(1,01-2,75)$ & 0,0437 \\
& 4 ou + & 1 & & \\
Horas & & & & 0,0014 \\
& 30 ou + & 1,95 & $(1,35-2,82)$ & 0,0004 \\
& 1 a 29 horas & 1,00 & $(0,65-1,56)$ & 0,9674 \\
& 0 horas & 1 & & \\
Filhos $<5$ & 2 ou + & 1,65 & $(1,21-2,24)$ & 0,0013 \\
& 1 & 1 & &
\end{tabular}

* Valores de odds ratio ajustados pela renda expressa em tercis e idade da criança.

Quadro 4 - Modelo de regressão logistica. Sul Urbano.

\begin{tabular}{lllll}
\hline Variável & Categorta & 0. R. & I.C. & p \\
\hline Escola & Analfabeta & 5,23 & $(1,83-14,91)$ & 0,0047 \\
& $\begin{array}{l}1 \text { a } 3 \text { anos } \\
4 \text { ou }+\end{array}$ & 2,89 & $(1,22-6,83)$ & 0,0154 \\
& 1 & 3,61 & $(1,59-8,15)$ & 0,0020 \\
TV & Não possui & 1 & & \\
& Possui & 4,30 & $(1,30-14,10)$ & 0,0166 \\
Filhos $<5$ & 2 ou + & 1 & & \\
& 1 & & &
\end{tabular}

* Valores de odds ratio ajustados pela renda-expressa em tercis. 
Quadro 5 - Modelo de regressão logística. Regiâo Sul Rural.

\begin{tabular}{lllll}
\hline Variável & Categoria & O.R. & I.C. & P \\
\hline Escola & Analfabeta & 5.51 & $(2,85-10,64)$ & 0,0000 \\
& 1 a 3 anos & 2,26 & $(1,16-4,39)$ & 0,0155 \\
& 4 ou + & 1 & & \\
& & & & 0,0831 \\
Horas & 30 ou + & 0,50 & $(0,27-0,94)$ & 0,0312 \\
& 1 a 29 horas & 1,11 & $(0,48-2,55)$ & 0,8031 \\
& 0 horas & 1 & &
\end{tabular}

* Valores de odds ratio ajustados pela renda expressa em tercis. 


\section{DISCUSSKO}

\subsection{Discussão dos resultados}

A discussão dos resultados do presente trabalho requer algumas consideraç̃es acerca do desenho do estudo. Estudos transversais trazem consigo limitaçóes inerentes à sua própria natureza que devem ser levadas em conta a fim de se evitar errôneas interpretações de resultados. 0 déficit de altura/idade considerado como um retardo no crescimento linear pode refletir, em menores de dois anos, o estado nutricional atual, mas em criancas maiores, a baixa estatura passa a ser um reflexo de retardo de crescimento acumulado no passado e de difícil reversão. Nesse sentido, o estudo transversal apresenta um problema de temporalidade já que as medidas e informações são basicamente limitadas ao momento de realizacão da pesquisa, dificultando o conhecimento acerca do tempo de atuação de determinados fatores sobre a desnutrição infantil.

No entanto, deve ser ressaltado que este trabalho não pretende chegar a respostas definitivas, mas sim sugerir a existência de possiveis riscos de desnutrição infantil que possam ser futuramente melhor explorados. Nesse sentido, é importante se obter resultados que cobrem grandes e distintas áreas geográficas do pais, mesmo que, em nivel de detalhamento de informaços, a PNSN não forneca mais respostas especificas às questros colocadas pela investigacão. 
Este estudo, realizado a partir da hipotese de que o déficit altura/idade em menores de cinco anos encontra seus determinantes no cuidado infantil, identificou diferentes fatores de risco nos quatro contextos estudados. A escolaridade materna é fator coincidente entre as regiôes.

O papel da escolaridade materna como determinante da desnutrição infantil tem sido amplamente reconhecido pela literatura (Cochrane 1980; Ware 1984; Cleland \& Ginneken 1988). Os estudos mostram que o efeito da educação materna sobre o estado de saúde infantil pode ser atenuado quando se inclui outros fatores sócio-econômicos na análise, entretanto não deixa de sè manter substancialmente importante. De uma maneira geral, os trabalhos indicam que os fatores sócio-econômicos podem ser responsáveis por cerca de $50 \%$ da aparente associação entre a escolaridade materna e a saúde infantil (Cleland \& Ginneken,1988). Victora e col.(1992), num estudo de coorte prospectiva, confirmam o efeito independente da escolaridade materna sobre a desnutrição infantil. Os autores mostram que a associação entre a educação materna e indices nutricionais se mantém expressiva mesmo após o ajuste por outras variávels sócioeconômicas. E importante ressaltar também que os trabalhos realizados por Victora e col. (1986a) e (1986b) e Olinto e col.(1993), encontram forte associacão para o grau de escolaridade do pai. Tais estudos restringem-se ao estado do Rio 
Grande do sul ou a determinadas áreas ou muntcípios do estado e não à Região Sul como um todo.

O efeito da educação materna sobre a saúde infantil pode ainda estar sujeito a um viés de seleção na medida em que mulheres mais escolarizadas se originam, mais provavelmente, de famillas melhor situadas na escala sôcio-econômica. Alêm disso, a duração da educação poderia estar associada a habilidades intelectuais ou outras caracteristicas pessoais da mulher relacionadas a tipos de personalidade ou mesmo a fatores culturais. Simons (1992), baseando-se em evidências sóciodemográficas, sugere que as atitudes maternas em relação ao cuidado infantil são transmitidas à mulher por seus pais e são caracteristicas de sua cultura ou sub-cultura. Em suma, dentro desta perspectiva, a herança cultural da mulher seria mais importante que sua propria escolaridade, na medida em que determinaria o padrão de cuidados dirigidos à criança em função de valores relativos ao papel da mãe e da importância da própria criança na sociedade.

Por outro lado, a importância do viés da seletividade é questionada por Cleland \& Ginneken (1988). Numa extensa revisão sobre o assunto, os autores argumentam que a questão pode ser relevante em países onde a mulher é privada do direito à educaço, mas perde muito da sua forca quando se refere a locais onde o acesso à educação é amplo, senão universal. Assim, sugerem os autores que a persistencia da associação entre escolaridade 
materna e sobrevivência infantil em sociedades que variam em termos de acesso à escola e em níveis de escolaridade atingidos pela mulher adulta indicam uma menor importância do viés de seletividade.

Os resultados do presente estudo parecem confirmar os achados de Cleland \& Ginneken (1988), pois apesar das enormes diferenças sócio-econômicas e culturais existentes entre as Regiões Nordeste e Sul, o que engloba os diferentes patamares atingidos na área da escolarização, a educação materna é o fator que apresenta o risco mais expressivo tanto nas áreas urbanas como nas murais, mesmo após o controle da renda familiar. No setor urbano da Região Nordeste, mães analfabetas têm um risco quase três vezes maior de ter um filho desnutrido que uma mãe de 4 ou mais anos de estudo. Já a baixa escolarização, de 1 a 3 anos de estudo, não se mostrou significante. No Sul Urbano, ter baixa escolaridade equivale a um risco de 2,89 que corresponde a mais da metade do risco imputado às mães analfabetas (odds ratio = $5,23)$. Nos contextos marais das duas regibes, as duas categorias relativas à educacão materna constituem-se risco, sendo sempre mais expressivo o risco correspondente ao analfabetismo.

0 trabalho da mãe apresentou resultados de direções opostas entre as regiões, ou seja, ora apresenta-se como fator de risco, ora como fator de proteçăo da desnutriçăo. A literatura tem discutido qual seria na verdade o efeito do trabalho materno sobre o bem estar da criança nos paises do Terceiro Mundo. Se por 
um lado, o trabalho materno aumenta a renda familiar, por outro, ele priva a criança dos cuidados maternos. Trabalhos realizados em diferentes regiöes do mundo e compilados por Leslie \& Paolisso (1989) indicam que não se pode assumir generalizações sobre a questão. E preciso sim, conhecer caracteristicas-chave do trabalho feminino para que se possa dizer alguma coisa acerca do seu possivel efeito sobre a saúde infantil. Entre tais características destacam-se o número de horas, remuneração obtida, benefícios do trabalho, substituição da mãe durante as horas de trabalho, etc.

No presente estudo, trabalhar poucas horas por semana no Nordeste Urbano não mostrou nenhuma associação com a desnutrição infantil, mas acima de 30 horas significa proteção para a criança $($ odds ratio $=0,45)$. Tal resultado parece coerente frente à baixa remuneração do trabalho na região, onde apenas um número maior de horas estaria garantindo uma melhoria na qualidade de vida da família. A partir da década de 70 tem havido uma significativa oferta de trabalho no setor público no Nordeste. Este tipo de trabalho no setor terciário, que tem absorvido um grande contingente de trabalho feminino, apresenta vantagens em relação ao setor privado devido à sua maior remuneração e aos benefícios socials oferecidos. Já o trabalho realizado em um número menor de horas tende a ser aquele trabalho do setor informal, que além da balxa remuneraçăo, năo oferece nenhuma garantia de serviços ou assistência à mulher e a seus filhos. 0 estudo de Rea e Solimano (1980) constatou uma menor taxa de amamentação entre as 
trabalhadoras do setor informal e com uma menor carga horária de trabalho fora de casa. Este tipo de atividade estaria associado a uma insegurança e intranquilidade no trabalho, bem como a uma necessidade de produzir que seriam prejudiciais ao cuidado infantil.

Por outro lado, no Nordeste Rural, o trabalho materno acima de 30 horas está associado a um risco cujo odds ratio é de 1,95 . Este fato também parece coerente com a realidade local. Enquanto que o trabalho priva a criança dos cuidados maternos, as condições de trabalho bem como sua remuneração não são nada favoráveis à mulher. Vários estudos retrataram a condição de vida da trabalhadora rural no Nordeste (Heréria 1979, Paulilo 1982, Bruschini 1989, Souto Maior 1988), e deles se depreende as - péssimas condições de vida e de trabalho dos nordestinos rurais. Boa parte da produção agrícola é realizada através de atividades familiares onde predomina um sistema ainda bastante tradicional de trabalho. Nesse sistema a mulher trabalha sem nenhuma remuneração. Quando a produção se estende além da esfera da subsistência, quem comercializa a produção e o homem ou, na sua falta, o filho mais velho. Quando o trabalho $\dot{\epsilon}$ assalariado, muitas vezes quem recebe o salário da mulher é o marido. A falta de recursos e de autonomia da mulher não estão de nenhuma forma relacionadas ao peso da sua participaçáo no trabalho, que ao contrário, é intensa. 
Se para a mulher rural há uma maior possibilidade de conciliar papéis, nada indica que seu trabalho seja gratificante ou garanta seus direitos. As crianças pequenas não impedem a mulher de trabalhar. Há relatos de mães que deixam os filhos pequenos sozinhos em casa, dentro da rede, de onde ainda não sabem descer e que quando são maiores já vão cuidando dos mais novos.

"As crianças pequenas, eu deixava dentro de casa e, quando era bem cedo, arrumava a casinha do jeito que eu pudesse... aí ia pro rocado. Quando era mais ou menos umas dez horas, eu chegava em casa fazia o almoco. Ai ia buscar um pal de lenha, um negócio que faltasse, ia botar os bichos na sombra. Ai, quando era tarde ia pro rocado. Quando era assim por volta das quatro horas ell largava, ai largava as crianças, ia ajeitar, dar de jantar. Quando amanhecia o dia, da mesma forma..." (Paulilo 1982)

A gravidez também não é empecilho para as mulheres trabalharem:

"Eu trabalhava até o dia do menino nascer. Dentro do rocado, eu trabalhando..." "Vinte dias depois (do parto), vinte dias depois estou no cabo da enxada fazendo todo servico. Fui mäe de doze nessa carreira" (Paulilo 1982).

Como se pode notar, o pesado esquema de trabalho a que $\varepsilon$ submetida a mulher trabalhadora no Nordeste Rural, praticamente 
em todas as fases do seu ciclo vital, termina por interferir na sua capacidade de cuidar adequadamente de seus filhos. Vale salientar que dentre as regiões estudadas é no Nordeste Rural onde se localiza a maior prevalência de desnutrição, ou seja, $29,4 \%$ das crianças menores de cinco anos apresentam déficits de altura/idade - No Nordeste Urbano a prevalência corresponde a $20,7 \%$ enquanto que na Região Sul a PNSN detectou prevalências de $6,8 \%$ e $11,4 \%$ respectivamente para as áreas urbanas e rurais. B interessante ainda lembrar que é também no Nordeste Rural onde se encontra a menor duração de aleitamento materno do pais, com uma mediana correspondendo a apenas 38 dias (Leão e col., 1992). A negligência em relação a importância do aleitamento materno traz consequencias dramáticas, em especial para as classes mais pobres, traduzidas como doenças, diarréias e altas taxas de mortalidade infantil (Monteiro e col.1992c; Monteiro \& Rea,1988). No Nordeste Rural, a área mais pobre do pais, uma queda radical do aleitamento materno foi fortemente influenciada por programas de distribuição de leite em pó a partir dos anos 60, a exemplo da Campanha "Food for Peace" (Scheper-Hugres, 1984).

No Sul Urbano, o trabalho materno não mostrou associação com a desnutrição infantil, enquanto que no setor rural da Região Sul - trabalho da mãe mostra ser fator de protecão para a desnutrição. Ou seja, como nos demais contextos analisados, trabalhar poucas horas não mostra nenhuma associação, mas 0 trabalho acima de 30 horas reduz em 50\% o risco de desnutrição. Não é possivel se referir com precisăo no presente estudo às 
diferenças existentes entre os sistemas de produção das áreas rurais do Nordeste e do Sul; no entanto, uma diferença básica reside no nivel de desenvolvimento dos meios de produção. Enquanto que no Nordeste Rural o sistema é ainda muito arcaico, no Sul mesmo quando se trata de produção a nivel familiar, observa-se a existêncla de um alto grau de mecanização no processo de produção agricola (Silva 1990). Por este motivo, além da esfera doméstica, observa-se uma divisão de trabalho mais clara, ou seja, enquanto que ao homem cabe cuidar da terra, comprar insumos e vender a produção, o trabalho maral da mulher fica mais circunscrito às proximidades do domicilio, já que a ela cabe cultivar verduras, ordenhar o leite e alimentar as galinhas e outros animais (Halsema,1991). Esta diferenca parece ser crucial quando se trata de cuidado infantil. Além disso, observese que o tipo de produto obtido através do trabalho da mulher é de alta importáncia para a alimentação infantil. Nesse particular vale salientar que, no Nordeste, a base de alimentação dos trabalhadores murais é o feijão, farinha de mandioca e cuscuz de milho, que são pratos feitos com o que é colhido por eles: "Num dia a gente não tem nadinha que nem... uma hipótese: eu não tenho nada hoje..., a gente vai no rocado, traz feijâo, traz macaxeira, traz um milho, faz um cuscuz... faz um prato de cuscuz pra dar pros meninos. Um rocado é colsa mito boa." (Paul11o, 1982:175).

Outro ponto a ser considerado nessa análise é a autonomia da mulher trabalhadora em relaça aos proprios afazeres domésticos. 
A evolução das relaços de poder entre os sexos mostra que no Sul Rural - ao contrário do Nordeste Rural, ainda extremamente conservador (Herédia 1979) - a mulher de hoje ostenta uma autonomia muito maior que aquela experimentada por suas mães, e esta autonomia se traduz também em normas e regras estabelecidas acerca de uma alimentação mais apropriada, higiene, e a correta educação de crianças (Halsema,1991).

Entre as variáveis demográficas, o número de filhos esteve associado com o deficit altura/idade, em alguns dos contextos estudados. Estes resultados são coerentes com evidências de que no Terceiro Mundo o número de filhos implica um significante fator de risco para a desnutrição infantil (Kucera,1991; Desai,1992). No Sul Urbano ter 2 ou mais filhos menores de 5 anos implica um risco 4,3 vezes maior em relação às mães que têm apenas 1 filho nessa faixa etária. Já no Nordeste Rural, este risco corresponde a 1,65 .

No setor urbano da Região Nordeste o risco da desnutrição das crianças menores de cinco anos está associado ao número de filhos de 5 a 10 anos de idade, onde a existência de 1 ou mais filhos nesta fáixa etária corresponde a um risco duas vezes maior quando se compara com a condicão definida como básal, ou seja, com a ausência de filhos.

A associaçăo negativa entre tamanho de familia e estado nutricional infantil ja foi encontrada por alguns autores 
(Aguillon,1982; Ballweg,1972). Por outro lado, há estudos mostrando que pré-escolares de famílias maiores apresentam um melhor status nutricional que aqueles pertencentes a familias de tamanho médio ou pequeno (Grewal e col.,1973; Gopaldas e col.,1988). A hipótese subjacente a este fato seria a probabilidade de haver nas familias maiores um maior número de mulheres adultas disponíveis para o cuidado infantil. Coerentes com esta hipótese, os resultados do presente estudo parecem apontar para o fato de que, mais do que o tamanho da família, importa a sua composicão. A análise da composição das famílias da amostra revela que é no Nordeste Urbano onde se encontram as famílias que contêm o maior número de moradores com idade superior a 10 anos de idade, correspondendo a uma média por família de 3,65 pessoas nessa condição, a maior média entre os quatro contextos estudados. Seria plausivel dizer que talvez por este fato no Nordeste Urbano não se tenha encontrado associação entre desnutrição e o número de crianças menores de 5 anos; estas estariam de uma certa maneira sendo protegidas pelo cuidado de pessoas mais velhas. Facchini (1995) em um extenso estudo sobre o trabalho materno e desnutrição infantil observou que nas familias maiores, uma maior rede de apoio familiar facilitava as alternativas domésticas de cuidado infantil, que além de liberar a mãe para o trabalho remunerado, potencializava o ganho de peso das crianças.

0 fato de a presenca de uma ou mais criancas de 5 a 10 anos de idade constituir-se num risco de desnutriçáo duas vezes maior 
para as menores de 5 anos no Nordeste Urbano quando se compara com a ausência de crianças nesta faixa etária no domicilio, poderia ser explicado tanto pela competição deles em termos de tempo de cuidado como na competição pela distribuição de alimentos. No entanto, as informações fornecidas pela PNSN por si só não permitem nenhuma afirmação a esse respeito.

A posse de TV no domicílio constitui-se nesse estudo numa variável de expressiva importância enquanto fator de proteção para a desnutrição nos contextos urbanos. No Nordeste Urbano, não possuir televisão configura-se num risco de 2,16 em relação a situação oposta, ou seja possuir TV. No Sul Urbano, o risco da desnutrição para a condição de não possuir TV é equivalente a 3,61 .

Atraves apenas das informações fornecidas pela PNSN năo se pode afirmar quais seriam os mecanismos de ação das telecomunicacöes enquanto fator protetor da desnutrição infantil, má na medida em que se tem os resultados do estudo controlados pela renda familiar per capita, pode-se dizer que o seu papel seguramente transcende aquele de ser mais um indicador do nivel de vida. Hakkert (1986) mostra a relevância do fator através da análise log linear da anostra de $1 \%$ do Censo Demográfico de 1970 e coloca a importância da discussão acerca do papel da televisão como transmissor de uma "educação difusa". Exemplos concretos taís como a campanha do soro caseiro e a do aleitamento materno (Monteiro e col.,1992c) mostram que nåo se pode negar a 
importância da televisão bem como da mídia em geral como importantes veículos para a saúde pública.

O Programa Nacional de Incentivo ao Aleitamento Materno (PNIAM) lancado no Brasil em 1981 foi disseminado basicamente pelos melos de comunicação de massa, embora outras atividades tivessem sido desenvolvidas (Rea \& Berquó,1990). As avaliações do PNIAM mostram que o programa contribuiu para reverter o perigoso declínio observado nas práticas de aleitamento que ocorreram no país nos anos 70. 0 impacto do programa fez aumentar sensivelmente as médias de amamentação, tanto exclusiva como parcial. Observou-se ainda que embora as coortes nascidas nos anos que se seguiram a implantação da campanha tenham se beneficiado, posteriormente ocorre uma queda no aleitamento quando a campanha sofre descontinuidade (Rea,1990; Rea \& Berquó, 1990)

\subsection{Considerações finais}

Os resultados emergentes desse trabalho trazem informações que podem contribuir para o planejamento e implementação de politicas públicas dirigidas à criança.

Desde o estudo histórico de Caldwell (1979) sobre os mecanismos de ação da educação materna sobre a saúde infantil, a hipotese de que a escolaridade materna seria a geradora de 
capacidades e habilidades fundamentais para o bem-estar da criança tem norteado as discussões travadas acerca do papel da mulher na luta pela sobrevivência de seus filhos. A evolução do debate tem, mais recentemente, enfatizado a importância de se propiciar à mulher uma maior autonomia de decisões e controle de recursos financeiros (McCracken \& Lovell,1992; Unicef,1990; United Nations, 1991). Tem sido cada vez mais demonstrado que nos páses do Terceiro Mando, onde o Estado encontra-se longe de cumprir com suas obrigações em termos de oferecer os direitos dos cidadãos, a saúde da criança bem como a sua sobrevivência ficam em grande parte dependendo de cuidados e estratégias formuladas pela mãe.

A escolaridade materna destacou-se neste estudo como um importante fator associado à desnutrição de pré-escolares. A queda nos indices da desnutrição no Brasil observada entre as décadas de 70 para 80 , ocorrendo de forma concomitante com a melhoria nos indicadores educacionais femininos (ver capitulo 3 ) levanta a plausibilidade de se concluir que a queda da desmutricão no período esteve associada à melhoria dos indicadores educacionais da mulher brasileira.

Com relação ao trabalho feminino no Brasil, o aumento da participação da mulher na força de trabalho entre as décadas de 70 e 80 ocorre enquanto que os percentuals da desnutricão infantil no período caem. Embora possa parecer uma generalização grosseira associar estes dois tipos de dados, os resultados do 
presente estudo oferecem indícios acerca da sua relação. No setor rural da Região Nordeste, o trabalho feminino é risco para a crianç, fato não surpreendente pois a sua existência tende a suprimir os cuidados infantis essenciais à saúde da criança, dada a natureza e condições do trabalho e de sua remuneração. Acrescese a isto $\circ$ fato de ser o Nordeste Rural a região mais desfavorecida do país em termos de assistência à satide e outros serviços públicos (Benício e col.,1992), o que contribui para agravar $\circ$ quadro de saúde de crianças filhas de mães trabalhadoras. Já no Nordeste Urbano e Sul Rural o trabalho materno mostra-se favorável à saúde infantil. Estudos realizados em determinadas áreas da Região Sul confirmam a importância do trabalho materno remunerado como fator protetor do déficit altura/idade (Olinto e col,1993; Facchini e col.1992). Nestes estudos, o acesso a bens e serviços, propiciados em parte pela remuneração do trabalho, mostrou ser de grande importancia na determinação do estado nutricional infantil. Facchini (1995) observa que a participação da mãe em atividades remuneradas guarda intima vinculação com a aquisição de bens eletrodomésticos, especialmente daqueles relacionados à conservação e preparação dos alimentos: Neste caso, a disponibilidade crescente de geladeira à medida que aumentava a inserção materna no trabalho remunerado, mostrou um impacto positivo da presença deste eletrodoméstico no domicílio sobre o ganho de peso infantil; o que se daria atraves de uma conservação mais adequada dos alimentos. 
Na literatura, o impacto do trabalho materno sobre a saúde infantil é contraditório. No entanto, o debate tem evoluído de uma polarização entre prós e contras para um maior aprofundamento da questão, na medida em que as pesquisas vêm mostrando que não é - trabalho en si que poderia ser prejudicial ao bem estar infantil, mas sim as condições em que é realizado (Leslie \& Paolisso, 1989).

Leslie (1989) imputa, ainda, os resultados conflitantes ou opostos encontrados para o efeito do trabalho materno sobre a saúde infantil a inconsistências metodológicas. A autora indica alguns problemas que podem ter causado as diferenças observadas em diferentes estudos. Entre estes destacam-se inadequações no tamanho da amostra, problemas relativos a definição e medida de algumas variáveis chave tais como local de trabalho (setor formal ou informal), a falta de preocupacåo com a disponibilidade e qualidade do substituto materno e outros. Ereciso ter em mente ainda, ao se comparar diferentes estudos, as possiveis inadequações dos métodos estatísticos utilizados e no controle de fatores de confusão presentes (Facchini,1995).

Como fá mencionado anteriormente, ainda é muito escassa a literatura disponivel para a compreensăo de um tema que se mostra tão complexo. Pode-se argumentar ainda que às inconsistências observadas entre os achados não se devem apenas a problemas metodológicos, mas também a complexidade das inter-relaçóes entre os diferentes fatores que compóm a questão trabalho materno e 
desnutrição infantil. Assim, a simples detecção do efeito positivo ou negativo do trabalho materno sobre a saúde infantil não é suficiente para elucidar a questão. E necessário, também, identificar os mecanismos através dos quais o trabalho da mãe afeta as práticas alimentares infantis bem como outros aspectos do cuidado da criança, e quais fatores estariam mediando estes mecanismos.

0 presente estudo, pelo fato de incluir análise do efeito do trabalho materno em contextos sócio-econômicos tão distintos, supera parte dos problemas metodológicos acima citados. Os resultados opostos obtidos para as regiões estudadas, a partir do uso de uma mesma metodologia de análise estatística, e de uma mesma amostragem, reforcam por um lado, a complexidade da interrelação trabalho materno/estado nutricional infantil. Por outro lado, legitimam as conclusões obtidas acerca do efeito do trabalho materno quando compreendidas dentro das particularidades sócio-econômicas de cada um dos contextos estudados.

Neste sentido, os achados deste estudo indicam que o trabalho materno é importante sim, para o bem-estar infantil, desde que as condições deste trabalho sejam minimamente dignas. preciso, portanto, que as autoridades e as proprias mulheres continuem a dirigir esforcos para a melhoria do status do trabalho feminino. 
Estudos feministas sobre a insercão da mulher brasileira no mercado de trabalho mostram que, apesar dos espacos conquistados, as mulheres continuam enfrentando discriminações que as afetam não apenas em aspectos psicológicos ou morais, mas principalmente em aspectos concretos do seu cotidiano (Bruschini,1989 e 1994; Merchant,1990). Para dissolver os efeitos danosos desta discriminação que terminam por chegar até a criança, é preciso que o delineamento de politicas sociais considerem alguns pontos básicos. Por um lado, é necessário favorecer a existência de oportunidades semelhantes de trabalho para homens e mulheres, superando assim a concentração de mulheres em guetos ocupacionais com consequiências danosas sobre os rendimentos recebidos. Por outro lado, é preciso que questões relativas aos ciclos de vida da mulher como a gestação, parto e aleitamento materno sejam respeitadas pelo esquema de trabalho e que se garanta a implantaçáo, para todas as categorias de trabalhadoras, dos direitos adquiridos na Constituicâo de 1988 (Brasil,1988). Vale ressaltar que a Constituição vigente, graças a organização e luta das mulheres, ampliou os direitos da maternidade para várias categorias, incluindo as empregadas domésticas e trabalhádoras rurais. No entanto, a alocação de tempo e recursos para o cuidado da crianca vai muito além dos quatro meses de licenca maternidade. E preciso que haja compromisso por parte das autoridades e empregadores no sentido de respeitar dispositivo também presente na Constituição vigente, de implantar creches conduzidas por pessoal qualificado e e em número suficiente. A continuidade deste cuidado viria com uma politica educacional que 
estimulasse calendarios escolares mais longos, pressupondo-se uma pré-escola e escola de primeiro grau públicas e de qualidade, que respondessem as necessidades da infância. Isto implicaria em cuidados que se estendessem, além do desenvolvimento cognitivo e social da criança, para as suas necessidades de nutrição e saúde.

Já no nivel doméstico, os cuidados infantis, bem como os cuidados em geral com a casa, devem ser considerados como responsabilidade dos membros da família em geral e não apenas das mulheres. Desta maneira, propostas mais avançadas desenhadas para facilitar a conciliação entre trabalho e cuidado infantil deveriam buscar facilidades especiais para que os trabalhadores de ambos os sexos pudessem mais facilmente conciliar suas múltiplas tarefas.

Portanto, a incorporação das mulheres no trábalho de forma desejável e favorável ao bem-estar infantil deve respeitar as suas necessidades $e$ as da própria criança. Paralelamente, a elevação da escolaridade das mulheres, além dos benefícios inerentes à aquisição de conhecimentos e todos os seus desdobramentos $j a ́$ discutidos neste trabalho, contribui para elevar o patamar de rendimentos e também para garantir à mulher um maior poder reivindicatório acerca dos direitos trabalhistas, beneficiando a si e a própria crianca. Vale lembrar que, conforme já mencionado anteriormente, a flexibilização de horários de trabalho, aliás uma das reivindicacões mais atuais das mulheres dos pafses avançados, e de fundamental importancia 
para o cuidado infantil, em particular para a extensão do aleitamento materno, tem sido prerrogativa de mulheres mais escolarizadas e com maior qualificacão profissional.

Em suma, os resultados deste estudo bem como a leitura de inúmeros outros que tratam da relação mãe/saúde da criança, seja sob qualquer ângulo de abordagem, mostram que o mundo infantil é indissociável do mundo materno. A forma como a mãe cuida do seu filho, ou, estando fora de casa, propicia condiçóes para o seu desenvolvimento, vai depender em grande parte da infra-estrutura social que o seu meio lhe oferece. Isto pode ser traduzido como educação formal e informal, disponibilidade de creches, de serviços de saúde, condições de trabalho e salários dignos, meioambiente saudável e outros. O bem estar infantil vai, ainda, depender muito do nivel de prioridade dado ao cuidado infantil por todos os membros da familia, o que pressupõe inclusive a divisão de tarefas domésticas. Estas constataçōes permitem dizer que muito pode ser feito pelo estado nutricional infantil se o Estado e a sociedade olharem para a criança atravês das suas mães e famílias.

As hipóteses testadas neste estudo, se por um lado confirmam e reforçam algumas das proposições básicas acerca da causalidade da desnutrição infantil como, por exemplo, a essencialidade da escolarização da mãe, por outro mostram como que determinados fatores podem ter efeitos opostos em diferentes contextos. Este é - caso, por exemplo, do trabalho materno cujo efeito parece 
depender de fatores relativos a estrutura familiar e de condições determinadas pela própria natureza do trabalho.

As conclusões que se seguem, podem de alguma maneira contribuir para a implementação de políticas públicas bem como para futuras pesquisas sobre cuidado infantil, tarefa acadêmica mas, também, política daqueles que lutam pelo fim das desigualdades e injustiças sociais nos países do Terceiro Mundo. 


\subsection{CONCLUSOES}

A análise dos dados da PNSN estudados a nível regional neste trabalho indicam que crianças menores de 5 anos estão mais propensas a desenvolver desnutrição crônica quando expostas a caracteristicas maternas ou domiciliares relacionadas ao cuidado infantil tais como:

NO NORDESTE URBANO:

- Analfabetismo materno.

- Maior número de filhos (neste caso a existência de 1 ou mais filhos na faira etária de 5 a 10 anos).

- Menor acesso à informação, medido pela ausência de televisão no domicilio.

NO NORDESTE RURAL:

- Analfabetismo e baixa escolaridade materna, sendo que o risco apresentado para filhos de mães analfabetas é mais expressivo do que aquele referente às máes de baixa escolaridade.

- Trabalho materno acima de 30 horas semanais.

- Maior número de filhos (neste caso a existência de 2 ou mais filhos na faira etárla de 0 a 5 anos). 
NO SUL URBANO:

- Analfabetismo e baixa escolaridade materna, sendo que o risco apresentado para filhos de mães analfabetas representa aproximadamente $\circ$ dobro daquele referente às mães de baixa escolaridade.

- Maior número de filhos (neste caso a existência de 2 ou mais filhos na faixa etária de 0 a 5 anos).

- Menor acesso à informação medido pela ausência de televisão no domicílio.

NO SUL RURAL:

- Analfabetismo e baixa escolaridade materna, sendo que o risco apresentado para filhos de mães analfabetas é maior que o dobro daquele referente às mães de baixa escolaridade.

O trabalho materno acima de 30 horas semanais apresentou-se, neste estudo, como fator de proteção à desnutrição de prêescolares no Nordeste Urbano e no Sul Rural. 


\section{REFERENCIAS BIBLIOGRAFICAS}

ABLAS,L.A.Q. Desequilíbrios regionais no desenvolvimento brasileiro.In:ROCCA,C.A.;BRAGA,C.A.P.;CACCIAMALI,M.C.;CASTRO, MC.de. Brasil 1980: Os desafios da crise económica. USP/FEA/Depart. Economia, 1980.

AGUILION,D.B.;CAEDO,M.M.;ARNOLD,J.C.;ENGEL,R.W. The relationship of family characteristics to the nutritional status of preschool children. Food Nutr.Bull., 4(4): 5-12, 1982.

ANDRADE,T.A. Desigualdades regionais:tendências de longo prazo. Perspectiva Económica Brasileira. Rio de Janeiro, IPEA/INPES, 1989.

BANCO MUNDIAL. Relatório sobre o desenvolvimento mundial 1990. São Paulo, Fundação Getúlio Vargas, 1990.

BALLWEG, J.A. Family characteristics and nutrition problems of preschool children in Fond Parisien, Haiti. J.Trop. Pediatr. Environ.Child Health, 18: 229-231, 1972.

BARAIGI, $R$. Is income the only instrument of child nutrition in mural Bangladesh? Bull World Health Org., 58(5): 767-772, 1980

BEGHIN,I.; CAP,M. \& DUJARDIN,B.A. Guide to Nutritional Assessment. Geneva, World Health Organization, 1988.

BENfCIO,M.H.D A; CESAR,C.L.G.; GOUVEIA,N.C. Perfil de morbidade e padrão de utilização de serviços de saúde das crianças brasileiras menores de cinco anos - 1989. In: PERFIL Estatístico de Crianças e Mães no Brasil. Aspectos de Saúde e Nutrição de Crianças no Brasil 1989. Rio de Janeiro, IBGE/NNICEF/INAN, p. 79-96, 1992.

BLEIBERG,F.; BRUN,A.T.; GOIHMAN,S.; GOUBA,E. Duration of Activities and Energy Expenditure of Female Farmers in Dry and Rainy Seasons in Upper Volta. British J. Nutr., 43: 71$82,1980$.

BOLTANSKI, L. As classes sociais e o corpo. Graal, Rio de Janeiro, 1979.

BRASIL. Constituição 1988. Constitituição: Repuiblica Federativa do Brasil. Brasilia, Senado Federal, 1988.

BRUSCHINI, C. Tendênclas da forca de trabalho feminina brasileira nos anos setenta e oitenta: Algumas comparacóes regionais. São Paulo, Fundaçăo Carlos Chagas, 1989. 
BRUSCHINI,C. A mulher no mercado de trabalho brasileiro na década de oitenta: uma comparação regional. Texto apresentado no seminário Mulher e Cidadania: Rumos e Descaminhos das Políticas Sociais. São Paulo, ABEP, maio/junho, 1994.

CALDWELL,J.C. Education as a factor in mortality decline. An examination of Nigerian data. Popul. Studies, 33(3): 395-415, 1979.

CALDWELL,J.C. \& CALDWELL,P. Education and literacy as factor in health. In: Halstead,S.B.; Walsh,J.A.;Warren,K.S. (Ed.) Good Health at Low Cost. New York, The Rockfeller Foundation, 1985.

CALDWELL,J.C. Routes to low Mortality in Poor Countries. Popul. Develop. Review, 12(2): 171-220, 1986.

CARVALHO, N. V. A condição feminina. São Paulo, Vértice/Editora Revista dos Tribunais, 1988.

CHAUDHURY,R.H. Adequacy of child dietary intake relative to that of other family members. Food Nutr. Bull., 10(2): 26-34, 1988.

CHEN, L.; CHOWDHURY,A.; HUFFMAN,S. Seasonal Dimentions of Energy Protein Malnutrition in Rural Bangladesh: The role of Agriculture, Dietary Practices and Infection. Ecol. Food Nutr., 8: 175-187, 1979.

CLELAND,J.G. \& GINNEKEN,G.K. Maternal education and child survival in developing countries: the search for pathways of influence. Soc.Sci.Med., 27(12): 1357-1368, 1988.

COCHRANE,S.H.; O'HARA,D.J.; LESLIE,J. The Effects of Education on Health. World Bank Working Paper no 405. Washington DC, World Bank, 1980.

CORNIA,G.A., JOLLY,R; STEWART,F. Adjustment with a human face. Protecting the vilnerable and promoting growth, vol 1. Oxford, Claredon Press, 1987.

DESAI,S. Children at risk: The role of family structure in Latin América and West Africa. Popul. Develop. Review, 18(4): 689$717,1992$.

DIAS,N.M.de 0. Mulheres "Sanitaristas de Pés Descalços". São Paulo, Hucitec, 1991.

DIBLEY,M.J. ;GODSBY,J.B. ; STACHING,N.W. ;TROWBRIDGE, F.L. Development of normalized curves for the international growth reference: historical and technical considerations. Am. J. Clin. Nutr., $46(5)$ : $736-48,1987$. 
DREZE,J. \& SEN,A. Humger and Public Action. Oxford, Claredon Press, 1989.

ENGLE,P. Child Strategies of Working and Nonworking Women in Rural and Urban Guatemala. In:Leslie, J. \& Paolisso, M. Women, Work, and Child Welfare in Third World. AAAS Selected Symposia Series 110; Boulder, Colorado, Westview Press, 1989.

ENGLE,P. Care and Child Nutrition. In: International Conference on Nutrition. Unicef, New York, 1992.

ENGLE,P. Influence of mothers and fathers income on children's nutritional status in Guatemala. Soc.Soi.Med., 37(11): 1303$1302,1993$.

FACCHINI, L.A.; TOMASI,E.; FASSA,A.C. Trabalho materno e ganho de peso em criancas menores de 5 anos de idade. In: Resumos do II Congresso Brasileiro de Epidemiologia, p.348, Belo Horizonte, 1992.

FACCHINI, L.A. Trabalho Materno e Ganho de Peso infantil. Pelotas, Editora e Gráfica Universitária - UFPel, 1995.

FAO/WHO Meeting the Nutrition Challenge (Framework Paper for the International Conference on Nutrition, to be held in December 1992), 1990. In UNITED NATIONS, Some Options for Improving Nutrition in the 1990s. Administrative Comittee on Coordination - Subcommittee on Nutrition. Suplement to SCN News no 7, 1991.

FIBGE Censo demográfico, 1970. Rio de Janeiro (80 recenceamento Geral,1970), v.1, 1972.

FIEGE. Metodologia do Estudo da Despesa Familiar - ENDEF. Manual de Instruções. Rio de Janeiro, 1974.

FIBGE. Pesquisa Nacional por Amostra de Domicilios, 1978. Rio de Janeiro, 1979.

FIBGE Anuário Estatístico do Brasil 1980. Rio de Janeiro, v.41, 1980.

BIEGE Anuivio Estatiatioo do Brasil 1981. Rio de Janeiro, 1981.

FIBGE Censo demográfico, 1980. Rio de Janeiro (90 recenceamento Geral, 1980), v.41, 1982.

FIBGE. Metodologia do Estudo da Despesa Familiar - ENDEF. Objetivos, descrição e metodologia usada no ENDEF. Rio de Janeiro, novembro, 1983a. (mimeo).

FIBGE. Metodologia do Estudo da Despesa Familiar - ENDEF. Núcleo de Banco de Informações ENDEF. Rio de Janeiro, novembro, 1983b. (mimeo). 
FIBGE Pesquisa Nacional por Amostra de Domicilios 1989, Rio de Janeiro, v.11., 1989.

FIBGE Anuário Estatístico do Brasil 1992, Rio de janeiro, 1992.

FLETCHER,P.R. Pesquisa Nacional sobre Salide e Nutrigão. Plano de Amostragem. Brasilia, 1988.

FURLANETTO,D.A. O processo de industrialização da Região Sul. In: Geografia do Brasil. Região Sul. Vol 2. IBGE. Rio de Janeiro, 1990.

GILLESPIE;S. \& MASON,J. Nutrition-Relevant Actions. Some experiences from the eighties and Lessons for the nineties. (ACC/SCN State-of-the-Art Series/Nutrition Policy . Discussion Paper n. 10), Geneva, United Nations, 1991.

GOPALDAS,T.; PATEL,P.; BAKSHI,M. Selected socio economic, environmental, maternal and child factors associated with the nutritional status of infants and toddlers. Food Nutr. Bull., $10(4): 29-34,1988$.

GRANTHAM-MCGREGOR, S. The Social Background of Childhood Malnutrition. Malnutrition and Behaviour: Critical Assessment of Key Issues. Nestlé Foundation Prblication Series, 4: 358$374,1984$.

GREWAL,T.;GOPALDAS,T.;GADRE,V.J. EtioloEy of malnutritionin maral Indian preschool children (Madhya Pradesh). J.Trop. Pediatr.Environ.Child Health, 19(3): 265-70, 1973.

GROSS,R. ;STANGE,M. ; SOLOMONS, N.W.;OLTERSDORF,U.;ESQUIVEL, I, R. The influence of economic deterioration in Brazil on the nutritional status of children in Rio de Janeiro, Brazil. Ecol. Food Nutr., 19: 265-279, 1987.

HAKKERT,R. Mecanismos subjacentes à relação entre a mortalidade infanto-juvenil e a educação dos pais. Rev. Bras. Est. Pop., $3(2), 1986$.

HALSEMA, I.van Housewives in the field. Power, culture and gender in a south Brazilian village. Latin American Studies, 59, 1991.

HEREDIA, B.M.A. A morada da vida: Trabalho familiar de pequenos produtores no Nordeste do Brasil. (Série Estudos sobre o Nordeste V.7), Rio de Janeiro, Paz e Terra, 1979.

HOLMBOE-OTTESEN, G.; MASCARENHAS, 0 . and WANDEL,M. Women's role in food chain activities and the implications for nutrition, (ACC/SCN State-of-the-art Series / Nutrition Policy Discussion Paper n.4), Geneva, United Nations, 1989. 
HORWITZ,A. Comparative Public Health: Costa Rica, Cuba and Chile. Food Nutr. Bull., 9(3): 19-29, 1987.

HOSMER, D.W. \& LEMESHOW, S. Applied Logistic Regression. New York, John Wiley \& Sons, 1989.

INAN - MINISTERIO DA SAUDE. Programa Nacional de Alimentacão $e$ Nutricâo - PRONAM 1976 - 1979. Documento Técnico INAN no 06/76.

INAN/IPEA/IBGE. Pesquisa Nacional sobre Salíde e Nutrição. Manual do Entrevistador - Questionário de Mão-de-Obra, Brasília, 1988a.

INAN/IPEA/IBGE. Pesquisa Nacional sobre Salude e Nutricáo. Manual do Entrevistador - Questionário de Saúde e Nutrição, Brasilia, 1988b.

INAN - MINISTERIO DA SAUUDE. Pesquisa Nacional sobre Saúde e Natriçáo - PNSN - 1989. Resultados Preliminares, Brasilia, 1990a.

INAN. Pesquisa Nacional Sobre Salide e Nutrição - PNSN -1989. Arquivo dos Dados da Pesquisa. Brasilia, abril, $1990 \mathrm{~b}$. (mimeo).

IUNES,F.R. \& MONTEIRO,C.A. Razões para a melhoria do estado nutricional das crianças brasileiras nas décadas de 70 e 80 . São Paulo, UNICEF/NUPENS/NSP, setembro, 1993.

JONSSON, U. The causes of hunger. Food Nutr. Bull., 3(2): 1-9, 1981

JELLIFFE,D.B.\& JELLIFFE,E.F.P. Hluman milk in the modern world. Oxford, Oxford University Press, 1979.

KUCERA,B. \& MCINTOSH,W.A. Family size as a determinant of children's dietary intake: a dilution model approach. Ecol. Food Nutr. 26(2): 127-137, 1991.

KUMAR,S.R. A framework for tracing policy effects on intrahousehold food distribution. Food Nutr. Bull., 5(4): 13-16, 1983.

LEXO,M.M.; COITINHO,D.C. ; RECIN,E.; COSTA,L.A.L. ; LACERDA,A., J. 0 perfil do aleitamento materno no Brasil. In: PERFIL Estatístico de Crianças e Mães no Brasil. Aspectos de Saúde e Nutrição de Crianças no Brasil 1989. Rio de Janeiro, IBGE/NNICEF/INAN, p. 97-109, 1992.

LEIBOWITZ,A. Education and Home Production. American Economic Review, 64: 243-250, 1974. 
LESLIE, J. Women's Work and Child Nutrition in the Third World. International Center for Research on Women. Washington D.C. 54pp., 1985.

LESLIE,J. Women's work and child nutritionin the Third World. In: LESLIE , J. \& PAOLISSO,M. Women, Work and Child Welfare in the Third World, AAAS Selected Symposia Series 110; Boulder, Colorado, Westwiew Press, 1989.

LESLIE,J. \& PAOLISSO,M. Women, Work and Child Welfare in the Third World, AAAS Selected Symposia Series 110; Boulder, Colorado, Westview Press, 1989.

LEWIN, H. Educação e Força de trabalho feminino no Brasil. Cadernos de Pesquisa, S.Paulo, 32: 45-59, 1980.

LINDENBAUM,S.; CHAKRABCOTY,M.; ELIAS,M. The influence of maternaI education on infant and child mortality in Bangladesh. Bangladesh/Dacca, International Centre for Diarrhoeal Disease Research, 1985.

LONGHURST, R Strategy for care and nutrition. Nutrition Section. New York, Unicef, July 1993. (Draft for Discussion).

LONGHURST, R. \& TOMKINS, A. The role of care in Nutrition - A neglected essencial ingredient. United Nations $S C N$ News, 12: $1-5,1995$.

LUCAS.A.; MORLEY,R; COLE,T.J.; LISTER,G.; LEESON-PAYNE.C. Leite de peito e subsequente quociente de inteligência em crianças prematuras. The Lancet, 339(1): 261-264, fev.1991. Tradução T.S. Toma e T.R.Filho. Documento do mês sobre amamentação no 1/95. UNICEF -IBFAN, Brasil, março 1995.

MADEIRA,F.R. \& SINGER,P.I. Estrutura do emprego e trabalho feminino no Brasil: 1920-1970. Cadernos Cebrap 13, São Paulo, 1975.

MCCRACKEN,S.D. \& LOVELL,P.A. Mother's roles, household arrangements and child survivorhip in Brasil. In: Sawyer,D.O. \& McCracken,S.D. The Young and the EIderly. Issues on morbidity and mortality. Belo Horizonte. UFMG/CEDEPLAR, 1992.

MCGUIRE,J.S. \& POPKIN,B.M. The zero-sum game: a framework for examining women and nutrition. Food Nutr. Bull., 10(3): 23$35,1988$.

MERCHANT,K. Women's Nutrition Through the life cicle: Social and Biological Vulnerabilities. Administrative Commitee on Coordination - Subcommittee on Nutrition. Geneva, United Nations, 1990. 
MIRANDA,G.V.de Education and other determinant factors of female labor force participation in Brasil. Stanford University, 1979. (PhD Theses)

MONTEIRO,C.A. \& REA,M.F. $O$ aleitamento materno. In: MONTEIRO,C.A. Salide e nutriçâo das crianças de São Paulo. São Paulo, Hucitec/ Ed. USP, 1988.

MONTEIRO,C.A.; BENfCIO,M.H.D'A.; IUNES,R.; GOUVEIA,N.C.; TADDEI,J.A.A.C.; CARDOSO,M.A.A. O Estado Nutricional das Criancas Brasileiras: A trajetória de 1975 a 1989. In: PERFIL Estatístico de Crianças e Mães no Brasil. Aspectos de Saúde e Nutrição de Crianças no Brasil 1989. Rio de Janeiro, IBGE/NNICEF/INAN, p. 43-59, 1992a

MONTEIRO, C.A.; BENfCIO,M.H.D'A.; IUNES,R.; GOUVEIA,N.C.; TADDEI,J.A.A.C.; CARDOSO,M.A.A. Nutritional status of Brazilian children: trends from 1975 to 1989. Bull. World Health Org., 70(5): 657-666, 1992b

MONTEIRO,C.A.;BENICIO,M.H.D'A.;GOUVEIA,N.C Salide e nutriç̃o das criancas brasileiras no final da década de 80 In: PERFIL Bstatístico de Crianças e Mães no Brasil. Aspectos de Saúde e Nutrição de Crianças no Brasil 1989. Rio de Janeiro, IBGE/NNICEF/INAN, p. 19-42, 1992c

MONTEIRO, C.A.; REA, M.; VICTORA,C. Can infant mortality be reduced by promoting breast-feeding? Evidence from São Paulo City. IN: Sawyer,D O. \& McCracken, S.D. The Young and the Elderly. Issues on morbidity and mortality. Belo Horizonte. UfMG/CEDEPLAR, $1992 \mathrm{C}$.

NARDI,B. Infant Feeding and Women's Work in Western Sudan: A hypothesis, some evidence and suggestion for future research. Ecol. Food Nutr., 8: 241-249, 1984.

NERLOVE,S. Women's Workload and Infant Feeding Practices: A Relationship with Demografic Implications. Ethnology, 13: 207-214, 1974.

OLINTO,M.T.A.;VICTORA,C.G.;BARROS, F.C.;TOMASI,E. Determinantes da desnutrição infantil em uma população de baixa renda: um modelo hierarquizado. Cad. Salide Pribl., Rio de janeiro, 9 (supl 1): 14-27, 1993.

OLIVEIRA, J.S. O traço da desigualdade social no Brasil. Rlo de janeiro, FIBGE, 1993.

PAULILO,M.I.S. A muiher no Brejo paraibano. Org. BRUSCHINO M.C.A. \& ROSEMBERG,F. Trabalhadoras do Bras11. Fundaç̃o Carlos Chagas. Brasiliense, São Paulo, 1982.

PEREIRA,L.C.B. Economia Brasileira: Uma Introducăo Crítica. Sqa Paulo, Brasiliense, 1982. 
PIWOZ,E.G. \& VITERI,F. Studying Health and Nutrition Behavior by Examining Household Decision-Making, Intra-Household Resource Distribution, and the Role of Women in these Processes. Food Nutr. Bul1., 7(4): 1-31, 1985

POPKIN,B.M. \& SOLON,F.S. Income, Time, the Working mother and Child Nutrition. J. Trop. Pediatr. Environ. Child Health, 22: 156-66, 1976.

POPKIN,B.M. Time Allocation of the Mother and Child Nutrition. Ecol. Food Nutr., $9(1): 1-14,1980$.

REA,M.F. \& CUKIER,R. Razões de desmame $e$ de introducão de mamadeira: uma abordagem alternativa para seu estudo. Rev. Saúde Pübl., S.Paulo 22(3): 184-91, 1988.

REA,M.F. \& SOLIMANO,G. Rethinking infant nutrition policies under changing socioeconomic conditions, São Paulo Project Presented in Rethinking Infant Nutrition Policies under Changing Socioeconomic Conditions. Oslo, Noruega, 1980.

REA,M.F. O programa nacional de amamentação no Brasil: Uma história bem sucedida. Int. J. Ginecol. Obstet., 31(supp1.1): $79-82,1990$.

REA,M.F. \& BERQUO,E.S. Impact of the Brazilian national breastfeeding programme on mothers in Greater São Paulo. Bull. World Health Org., 68(3): 365-371, 1990.

ROGERS,B.L. \& YOUSSEF, N. The Importance of Women's involvement in economic activities in the improvement of child nutrition and health. Food Natr. Bul1., 10(3): 10-17, 1988

ROSENZWEIG,M.R. and SCHULTZ,T.P. Child mortality and fertility in Colombia: Individual and community effects. Health Policy Educ., 2(3/4): 305-348, 1982.

SCHEPER-HUGHES, N. Infant mortality and infant care: cultural and economic constraints on nurturing in northeast Brazil. Soc. Sci. Med., 19(5): 535-546, 1984.

SERRA,J, Crescimento Econômico e condições básicas de vidá da população: notas sobre o caso do Brasil. In: Encontro da ABEP, Vitória, 1982, Anais. Vitória, 1986. p.51-77.

SHAH,P.M. Main Nutrition Problems During the Weaning Period and their Solution. International Conference of Nutrition, Rio de Janeiro, Brasil, 1978.

SILVA, S.T. Geografia do Brasil. Região Sul. Vol 2, IBGE, Rio de Janeiro, 1990. 
SIMONS, J. Components of cultural variation in the mothers contribution to child survival. IN: Sawyer,D O. \& McCracken, S.D. The Young and the Elderly. Issues on morbidity and mortality. Belo Horizonte. UFMG/CEDEPLAR, 1992.

SOUTO MAIOR, H.P. Mulher e trabalho no Nordeste nas estatisticas oficiais:1970-1985. Fundação Carlos Chagas/NFPE. Recife, 1988.

SOUZA,F.J.P. Pobreza e mortalidade infantil. Condicionantes sócio-econômicos. IPLANCE/UNICEF. Fortaleza, 1992.

SOUZA-LOBO,E. A Classe Operária tem dois sexos. Trabalho, dominaç̃o e resistência. São Paulo, Brasiliense, 1991.

THOMAS, D.; STRAUSS,J.; HENRIQUES,M.H. HOw does mother's education affect child heigh? Warwick University Summer Research Workshop, 1988. (mimeo)

UNICEF Strategy for Inproved Nutrition of Children and Women in Developing Countries. Policy Review Paper E/ICEF/1990/1.6, UNICEF, New York, 1990.

UNITED NATIONS, Comparative patterns of child mortality in developing countries. Department of International Social and Economic Affairs, United Nations, New York, 1985a.

UNITED NATIONS The Nairobi Forward-loooking Strategies for the Advancement of Women. In: Report of the World Conference to Review and Appraise the Achievements of the United Nations Decade for Women: Equality, Development and Peace. 15-26 July, Nairobi, Kenya, $1985 b$.

UNITED NATIONS Women and Nutrition, (ACC/SCN Symposium Report / Nutrition Policy Discussion Paper n.6), Geneva, 1990.

UNITED NATIONS. Some Options for Improving Nutrition in the $1990^{\circ} \mathrm{s}$. Administrative Commitee on Coordination - Subcommitee on Nutrition. Suplement to SCN News, n. 7, 1991.

UNDP Human Development Report 1991. United Nations Development Programme. Oxford University Press, 1991.

VAN ESTERICK,P. \& GREINER,T. Breastfeeding and Women's work: Constraints and opportunities. Studies in Family Planning, 12(4): $182-195,1981$.

VAN ESTERICK,P. Women, work and breastfeeding. In: 13th World Congress, Hong Kong, July, 1991. 
VIAL, J.; MUCHNIK,E. \& MARDONES,S.F. Women's Market Work, Infant Feeding Practices and Infant Nutrition Among Low-Income Women in Santiago,Chile. In Leslie and Paolisso,1989.op.cit., chapter 6:131-159.

VICTORA,C.G.;SMITH,P.G. \& VAUGHAN,J.P. Social and Environmental influences on child mortality in Brasil: logistic regression analysis of data from census files. J.Biosoc.Sci., 18: 87$101,1986 \mathrm{a}$.

VICTORA,C.G.; VAUGHAM,J.P.; KIRKWOOD,B.R.; MARTINES,J.C.; BARCELOS,L.B. Risk factors for malnutrition in Brazilian children:the role of social and environmental variables. Bull. World Health Org.; 64(2): 299-309, 1986b.

VICTORA,C.G.; HUTTLY,S.R.A.; BARROS,F.C.; LOMBARDI,C. \& VAUGHAN,J.P. Maternal education in relation to early and late child health outcomes: findings from a Brazilian cohort study. Soc. Sci. Med., 34(8): 899-905, 1992.

WALTER, M. Um novo olhar para os riscos da alimentação infantil artificial. J.Hum.Lact, 9(2): 97-107, 1993. Tradução T.S.Toma e T.R.Filho. Documento do mês sobre amamentação no $3 / 95$. UNICEF -IBFAN, Brasil, maio 1995.

WARE,H. Effects of maternal education, women's roles and child care practices on child mortality. Popul. Develop. Review, 10 (Supplement): 191-214, 1984.

WELCH, F. Education and Production. Journal of Political Economy, $78(2): 35-59,1970$.

WHO Working Group. Use and interpretation of anthropometric indicators of nutritional status. Bull. World Health Org., $64(6): 929-41,1986$. 
10. ANEXO

10.1 Etapas da modelagem.

10.1.1 Nordeste Urbano

A primeira variável a compor o modelo foi a escolaridade materna, a seguir acrescentou-se, uma a uma, as variáveis que apresentaram maior associação com a desnutrição na análise univariada, ou seja, horas de trabalho, TV, filhos de 5 a 10 anos (médios). Na seqüência, acrescentou-se também de forma separada, as variáveis filhos menores de 5

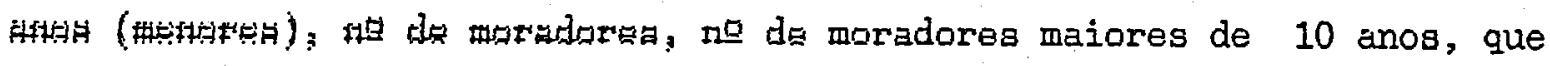
f nem tamprouco contribuírem de forma importante para o ajuste do modelo.

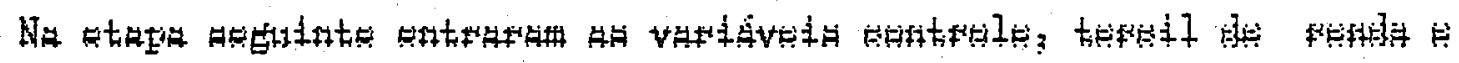
idade da criança (Icriança). 0 tercil de renda, embora năa sientifioante, mostrou ser variável de confusão além de contribuir bastante para 0 ajuste do modelo e portanto foi mantido. Além destes mesmos motivos, a idade da criança era ainda significante e obviamente também se manteve no modelo.

No final do processo de modelagem testou-se a existência de interação estatistica entre TV e Escola já que a primeira, ao entrar no modelo, se mostrou ser variável de confusão para a escolaridade materna, no entanto tal interação não foi significante. 0 mesmo ocorreu com os testes de interação entre Escola/Tercil e TV/Tercil. Testes de interaço foram feitos também entre Horas/Escola, Médios/Horas e Médios/Escola, mesmo na 
ausência de confusăo estatistica entre tais variáveis, o resultado porém foi não significante.

Quadro 6 - Etapas da modelagem: Nordeste Urbano

\begin{tabular}{|c|c|c|c|c|c|}
\hline MODELO & $\begin{array}{l}\text { Deviance } \\
(-2 L \mathrm{~L})\end{array}$ & $\mathbf{G}$ & $\mathrm{p}(\Delta \mathrm{GL})$ & $\begin{array}{l}\text { Parâm. } \\
\text { incl. }\end{array}$ & $\begin{array}{l}\text { Parâm. } \\
\text { excl. }\end{array}$ \\
\hline 1. Escola & 714,7 & - & - & Escola & - \\
\hline 2. Escola Horas & 698,8 & 15,9 & $<0.001(2)$ & Horas & - \\
\hline 3. Escola Horas TV & 678,5 & 20,3 & $<0.001(1)$ & TV & - \\
\hline $\begin{array}{l}\text { 4. Escola Horas TV } \\
\text { Médios }\end{array}$ & 659,8 & 18,7 & $<0.001(1)$ & Médios & - \\
\hline $\begin{array}{l}\text { 5. Escola Horas TV } \\
\text { Médios Menores }\end{array}$ & 649,5 & 10,3 & $<0,005(1)$ & Menores & - \\
\hline $\begin{array}{l}\text { 6. Escola Horas TV } \\
\text { Médios Morad. }\end{array}$ & 657,6 & 2,2 & n.s. (2) & Morad. & Menores \\
\hline $\begin{array}{l}\text { 7. Escola Horas TV } \\
\text { Médios Mor. }>10\end{array}$ & 659,1 & 0,7 & n.s. (2) & Mor $>10$ & Morad. \\
\hline $\begin{array}{l}\text { 8. Escola Horas TV } \\
\text { Médios Tercil }\end{array}$ & 634,8 & 25,0 & $<0,001(2)$ & Tercil & Mor.>10 \\
\hline $\begin{array}{l}\text { 9. Escola Horas TV } \\
\text { Médios Tercil } \\
\text { Icrianca }\end{array}$ & 617,0 & 17,8 & $<0,005(4)$ & Icriança & - \\
\hline
\end{tabular}


10.1.2 Nordeste Rural.

Iniciou-se o processo de modelagem com a varlavel escolaridade da mãe devido a sua maior significância na análise univariada. Na seqüência foi se adicionando ao modelo as demais variáveis, uma a uma, em ordem decrescente em função de sua significância estatística. Permaneceram no modelo as variáveis escolaridade materna, posse de televisão, número de filhos de 0 a 5 anos (menores) e horas de trabalho. Em seguida, as variáveis filhos de 5 a 10 anos (médios), número de moradores e número de moradores maiores de 10 anos foram descartadas por não apresentarem significância estatística, não serem variáveis de confusão e nem tampouco contribuirem para o ajuste do modelo.

Na fase seguinte acrescentou-se as variáveis controle: tercil de renda e idade da criança (Icriança). A entrada do tercil de renda fez com que se descartasse a variável posse de televisão, uma vez que esta perdeu significancia. O tercil de renda assim como a idade da criança foram variâveis significantes e contribuiram para o ajuste do modelo. 0 tercil de renda apresentou ainda confusão estatística com praticamente todas as demais variáveis do modelo.

No final do processo testou-se a existência de interações entre Escola/TV, Escola/Tercil, Escola/Horas, Horas/Menores, Menores/Escola, Menores/Tercil e IV/Tercil, no entanto nenhum dos testes foi significante. 
Quadro 7 - Etapas da modelagem: Nordeste Rural

\begin{tabular}{|c|c|c|c|c|c|}
\hline MODELO & $\begin{array}{l}\text { Deviance } \\
(-2 L L)\end{array}$ & $\mathrm{G}$ & $\mathrm{p}(\Delta \mathrm{GL})$ & $\begin{array}{l}\text { Parâm. } \\
\text { incl. }\end{array}$ & $\begin{array}{l}\text { Parâm. } \\
\text { excl. }\end{array}$ \\
\hline 1. Escola & 1342,6 & - & - & Escola & - \\
\hline 2. Escola TV & 1333,5 & 9,1 & $<0,005(1)$ & TV & - \\
\hline 3. Escola TV Menores & 1321,8 & 11,7 & $<0,001(1)$ & Menores & - \\
\hline $\begin{array}{l}\text { 4. Escola TV Menores } \\
\text { Horas }\end{array}$ & 1311,1 & 10,7 & $<0,005(2)$ & Horas & - \\
\hline $\begin{array}{l}\text { 5. Escola TV Menores } \\
\text { Horas Medios }\end{array}$ & 1309,5 & 1,6 & n.s. (1) & Medios & - \\
\hline $\begin{array}{l}\text { 6. Escola TV Menores } \\
\text { Horas Moradores }\end{array}$ & 1305,6 & 5,5 & n.s. (2) & Morad. & Médios \\
\hline $\begin{array}{l}\text { 7. Escola TV Menores } \\
\text { Horas Morad. }>10\end{array}$ & 1310,2 & 0,9 & n.s. (2) & Mor. $>10$ & Morad. \\
\hline $\begin{array}{l}\text { 8. Escola TV Menores } \\
\text { Horas Tercil }\end{array}$ & 1205,9 & 105,2 & $<0,001(2)$ & Tercil & Mor. $>10$ \\
\hline $\begin{array}{l}\text { 9. Escola Menores } \\
\text { Horas Tercil }\end{array}$ & 1209,8 & 3,9 & $<0,001(1)$ & - & $\mathrm{TV}$ \\
\hline $\begin{array}{l}\text { 10. Escola Menores } \\
\text { Horas Tercil } \\
\text { Icriança }\end{array}$ & 1173,7 & 36,1 & $<0,001(4)$ & Icriança & - \\
\hline
\end{tabular}


10.1.3 Sul Urbano

Assim como nas demais regiões, a modelagem no Sul Urbano teve inicio com a escolaridade da mãe. Foi seguida pela adição das variáveis TV, e no modelo seguinte, filhos menores de 5 anos (menores). Ambas foram significantes e apresentaram confusão estatistica para a escolaridade materna. As demais variáveis, filhos maiores de 10 anos (maiores), filhos de 5 a 10 anos (médios) e número de moradores no domicilio foram sendo adicionadas individualmente no modelo e retiradas por não apresentarem significância estatística. Das variáveis controle, idade da criança e tercil de renda, apenas a última foi mantida no modelo por ser variável de confusão para as demais.

Por último efetuou-se os testes de interação entre tercil e as demais variáveis do modelo e ainda entre Escola/TV, Escola/Menores e Menores/TV, não se tendo, no entanto, encontrado significância estatistica para nenhuma delas. 
Quadro 8 - Etapas da modelagem: Sul Urbano

\begin{tabular}{|c|c|c|c|c|c|c|}
\hline MODELO & $\begin{array}{l}\text { Deviance } \\
(-2 L \amalg)\end{array}$ & G & $p(\Delta G L$ & & $\begin{array}{l}\text { Parâm. } \\
\text { incl. }\end{array}$ & $\begin{array}{l}\text { Parâm. } \\
\text { excl. }\end{array}$ \\
\hline 1. Escola & 264,1 & - & - & & Escola & - \\
\hline 2. Escola TV & 248,1 & 16,0 & $<0,001$ & (1) & TV & - \\
\hline 3. Escola TV Menores & 242,8 & 5,3 & $<0.025$ & (1) & Menores & - \\
\hline $\begin{array}{l}\text { 4. Escola TV Menores } \\
\text { Maiores }\end{array}$ & 239,3 & 3,5 & n.s. & (1) & Maiores & - \\
\hline $\begin{array}{l}\text { 5. Escola TV Menores } \\
\text { Médios }\end{array}$ & 241,9 & 0,9 & n.s. & (1) & Médios & Maiores \\
\hline $\begin{array}{l}\text { 6. Escola TV Menores } \\
\text { Moradores }\end{array}$ & 242,8 & 0,0 & n.s. & $(2)$ & Morad. & Médios \\
\hline $\begin{array}{l}\text { 7. Escola TV Menores } \\
\text { Icrianca }\end{array}$ & 237,9 & 4,9 & n.s. & $(4)$ & Icriança & Morador \\
\hline $\begin{array}{l}\text { 8. Escola TV Menores } \\
\text { Tercil }\end{array}$ & 240,0 & 2,8 & n.s. & $(2)$ & Tercil & Icrian \\
\hline
\end{tabular}


10.1.4 Sul Rural

A modelagem teve início com a variável escolaridade materna seguida de TV e ambas se mantiveram no modelo. A seguir foram adicionadas, uma a uma, as variáveis filhos menores de 5 anos (menores), filhos de 5 a 10 anos (médios) e número de moradores no domicilio, que foram descartadas por não serem estatísticamente significantes. Posteriormente, ainda como fator de estudo, colocou-se a variável horas de trabalho que se manteve no modelo. A importância desta variável para o estudo fez com que, excepcionalmente, se ampliasse o nivel critico de significância estatistica para 10\%. Na etapa final entrou a variável controle idade da crianca que foi descartada do modelo. A seguir, a entrada do tercil de renda causa um superajuste no modelo devido a presenca da variável TV. Optou-se por retirar a variável TV do modelo e manter o tercil de renda, em função do interesse de se manter uniformizado o controle pela renda nas quatro regioes em estudo.

Testou-se, no final, as interações Escola/Tercil, Escola/Horas, Horas/Tercil, não se tendo, no entanto, encontrado significância estatistica para nenhum dos testes. 
Quadro 9 - Etapas da modelagem: Sul Rural

\begin{tabular}{|c|c|c|c|c|c|}
\hline MODELO & $\begin{array}{l}\text { Deviance } \\
(-2 L L)\end{array}$ & G & $p(\Delta G L)$ & $\begin{array}{l}\text { Parâm. } \\
\text { incl. }\end{array}$ & $\begin{array}{l}\text { Parâm. } \\
\text { excl. }\end{array}$ \\
\hline 1. Escola & 468,6 & - & - & Escola & - \\
\hline 2. Escola TV & 448,1 & 20,5 & $<0,001(1)$ & TV & - \\
\hline 3. Escola TV Menores & 445,7 & 2,4 & n.s. (1) & Menores & - \\
\hline 4. Escola TV Médios & 445,1 & 3,0 & n.s. (1) & Médios & Menores \\
\hline $\begin{array}{l}\text { 5. Escola TV } \\
\text { Moradores }\end{array}$ & 447,5 & 0,6 & n.s. (2) & Morad. & Médios \\
\hline $\begin{array}{l}\text { 6. Escola TV } \\
\text { Horas }\end{array}$ & 443,4 & 4,7 & $<0,100(2)$ & Horas & Morad. \\
\hline $\begin{array}{l}\text { 7. Escola TV } \\
\text { Horas Icriança }\end{array}$ & 437,4 & 6,0 & n.s. (4) & Icriança & - \\
\hline $\begin{array}{l}\text { 8. Escola TV } \\
\text { Horas Tercil }\end{array}$ & 432,1 & 11,3 & $<0,005(2)$ & Tercil & Icriança \\
\hline $\begin{array}{c}\text { 9. Escola Horas } \\
\text { Tercil }\end{array}$ & 443,8 & 11,7 & $<0,001(1)$ & - & TV \\
\hline
\end{tabular}


10.2 Número de "não resposta"

Encontram-se abaixo, nas tabelas 10,11, 12, e 13 informacões sobre o número de casos que efetivamente entraram no modelo de regressão logistica.

Tabela 10. Número de casos com informacões completas que entraram no modelo final de regressão logística. Nordeste Urbano

\begin{tabular}{lccc} 
Variável & N na categoria & N no modelo final & $\%$ \\
\hline Escola & & & \\
(1) analfabeta & 210 & 201 & 95,7 \\
(2) $1-3$ anos & 104 & 103 & 99,0 \\
(3) 4 ou + & 454 & 423 & 93,1
\end{tabular}

\section{Horas}

(1) zero

(2) 1 - 29 horas

(3) 30 ou mais

\section{TV}

(1) possui

(2) não possui

507

355

509

113

244

Filhos de 5 a 10 anos
(1) nenhum
(2) 1 ou mais
356
510

Tercil

(1) 10

(2) $2 \underline{0}$

(3) 30

245

278

319

Icriança

(1)

(2)

(3)

(4)

(5)
143

182

167

197

177
402

105

220

495

350

348

501

98,7

225

235

267

91,8

84,5

83,7

92,9

90,1

97,6

98,6

122

152

135

168

150
85,3

83,5

80,8

85,2

84,7 
Tabela 11. Número de casos com informacões completas que entraram no modelo final de regressão logistica. Nordeste Rural

\begin{tabular}{|c|c|c|c|}
\hline Variảvel & N na categoria & N no modelo final & $\%$ \\
\hline $\begin{array}{l}\text { Escola } \\
\text { (1) analfabeta } \\
\text { (2) } 1-3 \text { anos } \\
\text { (3) } 4 \text { ou }+\end{array}$ & $\begin{array}{l}650 \\
285 \\
206\end{array}$ & $\begin{array}{l}595 \\
270 \\
190\end{array}$ & $\begin{array}{l}91,5 \\
94,7 \\
92,2\end{array}$ \\
\hline $\begin{array}{l}\text { Horas } \\
\text { (1) zero } \\
\text { (2) } 1-29 \text { horas } \\
\text { (3) } 30 \text { ou mais }\end{array}$ & $\begin{array}{l}918 \\
145 \\
195\end{array}$ & $\begin{array}{l}737 \\
138 \\
180\end{array}$ & $\begin{array}{l}80,3 \\
95,1 \\
92,3\end{array}$ \\
\hline $\begin{array}{l}\text { Filhos < } 5 \\
\text { (1) } 1 \\
\text { (2) } 2 \text { ou mais }\end{array}$ & $\begin{array}{l}403 \\
855\end{array}$ & $\begin{array}{l}397 \\
843\end{array}$ & $\begin{array}{l}98,5 \\
98,5\end{array}$ \\
\hline $\begin{array}{l}\text { Tercil } \\
\text { (1) } 10 \\
\text { (2) } 20 \\
\text { (3) } 30\end{array}$ & $\begin{array}{r}692 \\
404 \\
83\end{array}$ & $\begin{array}{r}637 \\
346 \\
72\end{array}$ & $\begin{array}{l}92,0 \\
85,6 \\
86,7\end{array}$ \\
\hline $\begin{array}{l}\text { Icrianca } \\
(1) \\
(2) \\
(3) \\
(4) \\
(5)\end{array}$ & $\begin{array}{l}245 \\
290 \\
236 \\
231 \\
256\end{array}$ & $\begin{array}{l}207 \\
248 \\
199 \\
189 \\
211\end{array}$ & $\begin{array}{l}84,5 \\
85,5 \\
84,3 \\
81,8 \\
82,4\end{array}$ \\
\hline
\end{tabular}


Tabela 12. Número de casos com informaçóes completas que entraram no modelo final de regressão logística. Sul Urbano

\begin{tabular}{lrrr} 
Variável & N na categoria & N no modelo final & $\%$ \\
\hline Escola & & 38 & 92,6 \\
(1) analfabeta & 41 & 100 & 99,0 \\
(2) $1-3$ anos & 101 & 436 & 97,5 \\
(3) 4 ou + & 447 & & \\
TV & & 527 & 98,5 \\
(1) possui & 535 & 92 & 97,8 \\
(2) não possui & 94 & & \\
Filhos 5 & & 389 & 98,7 \\
(1) 1 & 394 & 232 & \\
(2) 2 ou mais & 235 & & 97,4 \\
Tercil & & 38 & 92,3 \\
(1) 10 & 39 & 117 & \\
(2) 20 & 131 & 419 & \\
(3) 30 & 455 & & \\
-
\end{tabular}

Tabela 13. Número de casos com informações completas que entraram no modelo final de regressão logistica. Sul Rural

\begin{tabular}{lrrr} 
Variável & N na categoria & N no modelo final & $\%$ \\
\hline Escola & & & \\
(1) analfabeta & 144 & 141 & 97,9 \\
(2) $1-3$ anos & 201 & 197 & 98,0 \\
(3) 4 ou + & 399 & 390 & 97,7 \\
Horas & & & \\
(1) zero & 477 & 437 & 91,6 \\
(2) $1-29$ horas & 71 & 67 & 94,3 \\
(3) 30 ou mais & 227 & 224 & 98,6 \\
Tercil & & & \\
(1) 10 & 159 & 151 & 94,9 \\
(2) 20 & 326 & 315 & 96,6 \\
(3) 30 & 283 & 262 & 92,5 \\
\hline
\end{tabular}

